\title{
La Casa de Juan I de Castilla: aspectos domésticos y ámbitos privados de la realeza castellana a finales del siglo XIV (ca. 1370-1390) ${ }^{1}$
}

\author{
The Household of John I of Castile: Private Spheres and Domestic \\ Aspects of Castilian Royalty in the late-fourteenth century \\ (ca. 1370-1390)
}

\author{
Francisco de Paula CAÑas GálveZ \\ Universidad Complutense. Madrid \\ franccan@ghis.ucm.es
}

\begin{abstract}
RESUMEN
La estructura de la Casa Real de Castilla durante la Baja Edad Media ha sido en los últimos años objeto de un notable interés por parte de la historiografía. Abordamos ahora por vez primera el estudio de la Casa de Juan I atendiendo a los aspectos más privados y cotidianos de la vida en la corte en aquellos años de profundas transformaciones políticas, culturales e institucionales en Castilla.
\end{abstract}

Palabras clave: Juan I de Castilla. Monarquía. Casa Real. Oficiales de Casa y Corte. Burocracia regia

\begin{abstract}
The structure of the Royal House of Castile during the Middle Ages has been the subject of important interest by historians in recent years. Now, for the first time, this article addresses the study of the Royal House of John I in response to the most private aspects of everyday life at court during years of profound political, cultural and institutional change in Castile.
\end{abstract}

Keywords: John I of Castile. Monarchy. Royal Household. Household and court offices. Royal bureaucracy

Sumario: 1. introducción. 2. Estructura de la Casa del rey de Castilla durante la segunda mitad del siglo xIv. 3. La Casa de Juan I. 3.1. Los mayordomos. 3.2. La cámara regia. Organización y economía. 3.2.1. Camareros mayores. 3. 2. 2. Las cámaras de la jineta y los paños y sus oficiales. 3. 2. 3. La armería real. 3. 3. La mesa del rey. 3. 4. La atención sanitaria: físicos y parteras en la corte de Castilla. 3. 5. Los divertimentos del rey: juglares y ministriles. Juegos de Navidad en la corte. 3. 6. La Capilla Real. 4. La caza regia: el papel protagonista de la cetrería en tiempos de Juan I de Castilla. 5. Conclusión. 6. Apéndice: listado de oficiales de la Casa de Juan I de Castilla.

${ }^{1}$ Este trabajo se ha realizado en el marco del proyecto de investigación financiado por el Ministerio de Ciencia e Innovación no HAR2010-16762/HIST titulado "Prácticas de consenso y de pacto e instrumentos de representación en la cultura política castellana (siglos XIII al XV)". Investigador principal: Dr. José Manuel Nieto Soria. 


\section{INTRODUCCIÓN2}

En la última década los trabajos consagrados al estudio de la Casa Real castellana durante el siglo XV se han multiplicado de manera muy notable ${ }^{3}$. No ha ocurrido así con el xiv, y muy especialmente con su segunda mitad, una etapa en la historia de Castilla caracterizada por profundas reformas estructurales que alteraron de manera determinante la vida institucional y política de la corte ${ }^{4}$. Esta carencia historiográfica, achacable, tantas veces, a la consabida escasez de fuentes documentales del periodo, ha impedido además analizar con detalle cómo y de qué manera afectaron las reformas iniciadas por Enrique II sobre las bases del aparato burocrático y administrativo de la Corona a los ámbitos más privados de la sociedad cortesana y de la vida regia y si supusieron una evolución lógica o, por el contrario, marcaron una ruptura con respecto a las estructuras administrativas y domésticas que habían predominado en la Casa Real castellana hasta entonces.

Son todas ellas cuestiones que pretendemos abordar en este trabajo. Conviene, sin embargo, matizar que nuestro objetivo será centrarnos únicamente en los oficios y los oficiales más cercanos a la persona regia, aquellos dependientes directamente de la supervisión del camarero mayor y de los que, aún supeditados a las órdenes del mayordomo mayor, tuvieron un papel significativo en los ámbitos más privados de la vida áulica. Los del aparato burocrático de la Corona y los militares del rey, así como los encargados de gestionar la logística de los viajes reales quedan ahora fuera de nuestro estudio y serán abordados en sucesivas publicaciones ya en curso de preparación.

${ }^{2}$ Las siglas y abreviaturas utilizadas en el presente trabajo han sido las siguientes: a. de. Antes de. ADM: Archivo Ducal de Medinaceli. AGN: Archivo General de Navarra. AGS: Archivo General de Simancas. AHN: Archivo Histórico Nacional. ASV: Archivo Secreto Vaticano. BN: Biblioteca Nacional. Carp: Carpeta. CySR: Casa y Sitios Reales. DC: Diversos de Castilla. d. de: después de. EMR: Escribanía Mayor de Rentas. Fol.: Folio. Leg.: Legajo. MyP: Mercedes y Privilegios. PR: Patronato Real. Ms.: Manuscrito. $\mathrm{n}^{\mathrm{o}}$ : número. p.: página. pp.: Páginas. PR: Patronato Real. QC: Quitaciones de Corte. r.: recto. RAH: Real Academia de la Historia. s/f.: sin foliar. vol.: Volumen. vols.: Volúmenes. v.: verso.

${ }^{3}$ Una reciente puesta al día de la bibliografía dedicada a la Casa Real de Castilla y León durante la Baja Edad Media en F. de P. CAÑas Gálvez, "Las Casas de Isabel y Juana de Portugal, reinas de Castilla. Organización, dinámica institucional y prosopografía (1447-1496)", en Las relaciones discretas entre las monarquías hispana y portuguesa. Las Casas de las reinas (siglos XV-XIX), Vol. I, Madrid, 2008, pp. 9-13; también mis trabajos El itinerario de la corte de Juan II de Castilla (1418-1454) Madrid, 2007; y "La cámara de Juan II: vida privada, ceremonia y lujo en la corte de Castilla a mediados del siglo xv", en Evolución y estructura de la Casa Real de Castilla, Vol. 1, Madrid, Ediciones Polifemo, 2010, pp. 81-195.De igual modo, siguen siendo de referencia las obras de M. A. LADERo QuESADA, "La casa real en la Baja Edad Media", Historia, Instituciones, Documentos, 25 (1998), pp. 327-350 y J. DE SAlazAr Y Acha, La casa del Rey de Castilla y León en la Edad Media, Madrid, 2000. Una visión de los oficiales regios con anterioridad a la época Trastámara en L. V. Díaz Martín, Los of ciales de Pedro I de Castilla, Valladolid, 1987.

${ }^{4}$ Para los primeros Trastámara en su vertiente puramente política véanse los libros de J. VALDEÓN Baruque, Enrique II. 1369-1379, Palencia, 1996; L. Suárez Fernández, Historia del reinado de Juan I de Castilla. Estudio y documentos , Madrid, 1977-1982, 2 vols.; y F. Suárez BILbao, Enrique III. 1390-1406, Palencia, 1998. Más reciente es el trabajo de R. SÁnchez Saus, Las élites políticas bajo los Trastámara. Poder y sociedad en la Sevilla del siglo XIV, Sevilla, 2009. 
Respecto a las fuentes utilizadas es necesario indicar la importancia de la Carta de finiquito de las cuentas del camarero Diego López de Estúñiga rendida en Medina del Campo el 20 de diciembre de 1380. Este destacado documento ha sido de singular valía a la hora de profundizar en diversos aspectos de la vida doméstica en los dos primeros años del reinado del segundo Trastámara ${ }^{5}$. Junto a él, la edición de los Documentos de Juan I conservados en el Archivo Municipal de Murcia ${ }^{6}$ y la crónica del reinado por Pero López de Ayala ${ }^{7}$, nos han permitido analizar con detalle la evolución institucional de la Casa del rey durante aquel periodo.

Con la intención de ofrecer al lector una exposición lo más ordenada posible, hemos optado por dividir este trabajo de investigación en diferentes áreas temáticas. Así, y tras una introducción, estudiaremos la estructura de la Casa del rey durante la segunda mitad del siglo XIv. Posteriormente abordaremos las particularidades de la Casa de Juan I comenzando por la mayordomía y siguiendo por las diferentes cámaras regias, los oficiales encargados de la salud de la Familia Real, los divertimentos reales, entre ellos la música y la caza, para finalizar con la Capilla Real como escenario espiritual, político y terrenal del poder de la Corona. En su parte final se incluye un listado de todos los oficiales de la Casa Real de Juan I que hemos podido documentar a lo largo de su reinado con las fechas de actividad de sus respectivos cargos.

\section{ESTRUCTURA DE LA CASA DEL REY DE CASTILLA DURANTE LA SEGUNDA MITAD DEL SIGLO XIV}

Con anterioridad al reinado de los Reyes Católicos no parece que existieran en Castilla disposiciones de funcionamiento que dispusieran una estructura definida, un "organigrama" en palabras de Salazar y Acha, de su Casa Real'. La segunda Partida de Alfonso X, en la que se describen los oficios más importantes de la corte, no puede ser considerada una ordenanza o reglamento, como tampoco lo son los ordenamientos de la Audiencia Real, Cancillería o Consejo Real de los años 1312, $1371,1374,1385$ o 1436 pues se trata de normas encaminadas a regular cuestiones concretas de determinados organismos de la Corona, principalmente en lo relativo a los aspectos fiscales y a corregir abusos y prácticas fraudulentas en el cobro de derechos arancelarios por parte de los oficiales'.

Un panorama, sin duda, muy diferente al que por entonces se vivía en la Corona de Aragón, donde desde tiempos de Pedro III el Grande se sucedieron las ordenanzas regias encaminadas a regular el funcionamiento y la organización de oficios y

\footnotetext{
${ }^{5}$ AHN, Nobleza, Osuna, Carp. 40, nº 1. Publicado por L. SuÁrez Fernández, Historia del reinado..., II. Documentos, 181, pp. 249-307; y por Ma L. DE Villalobos, "Las gestiones hacendísticas de Diego López de Estúñiga camarero de Juan I (Contribución al estudio de la economía y fiscalidad castellana bajo los primeros Trastámara)", Hispania, XLIII, (1983), pp. 159-206. A lo largo de este trabajo citaremos este documento por su signatura original en el Archivo Histórico Nacional.

${ }^{6}$ J. M. Díez Martínez, A. Bejarano y A. L. Molina Molina, Documentos de Juan I, Murcia, 2001.

${ }^{7}$ P. López de Ayala, Crónica del rey don Juan, primero de Castilla e de León, Edición de José Luis Martín, Barcelona, 1991.

8 J. de Salazar y Acha, La casa ..., p. 141.

${ }^{9}$ M. A. Ladero Quesada, "La casa real...", pp. 331 y 332.
} 
oficiales de la corte ${ }^{10}$. La publicación en 1337 de las Leges Palatinae de Jaime III de Mallorca vendría a culminar brillantemente aquellos primeros pasos dados a finales del siglo XIII con la consolidación de un modelo de organización cortesana que habría de perpetuarse en el tiempo. De la eficacia de aquel texto y de su rápida acogida en el marco hispánico de la época es buena prueba la traducción al catalán que en 1344 Pedro IV el Ceremonioso ordenara del original en latín, sus conocidas Ordinacions, a las que añadió pequeñas modificaciones y añadidos sin mayor relevancia, y su intento de exportación a Castilla como seguidamente tendremos ocasión de ver ${ }^{11}$.

De igual modo en Navarra todo parece indicar que desde principios del siglo XIV también hubo un marcado interés de la Corona por dotar a la Casa Real de unas estructuras administrativas sólidas y eficaces. De 1320, por ejemplo, son unas ordenanzas dictadas por el conde Felipe de Évreux (1319), más tarde rey navarro (1328), que, en sus líneas generales, venían a seguir el modelo establecido por Luis IX de Francia en el siglo XIII. Sobre ellas se debieron de redactar las posteriores ordenanzas de Carlos II y Carlos III de 1376, 1392, 1399, 1404 y 1406, aunque no se ha conservado el texto de ninguna de ellas ${ }^{12}$.

En el caso castellano, como se anunciaba unas líneas más arriba, no existieron nunca estas disposiciones, aunque sí es cierto que Casa Real contaba a mediados del siglo XIV con una estructura más o menos definida en la que se vislumbran ciertos signos o trazas de madurez institucional. López de Ayala nos ofrece interesantes datos sobre la composición de la Casa del rey tras la llegada de Pedro I al trono de Castilla. Según el cronista, ésta, heredera de la Casa de Alfonso XI en cuanto a sus oficios y oficiales, quedó conformada de la siguiente manera: alférez mayor (Juan Núñez de Lara), mayordomo mayor (Fernando de Castro), adelantado de Castilla (Garci Laso de la Vega) ${ }^{13}$, guarda mayor (Gutier Ferrández de Toledo) ${ }^{14}$, copero (Alfonso Ferrández Coronel), oficial de la escudilla (Ferrand Pérez Portocarrero) ${ }^{15}$, camarero (Pero Suárez de Toledo ${ }^{16}$ ), repostero (Pero Suárez de Toledo el Mozo) ${ }^{17}$,

${ }^{10}$ Siendo infante de Aragón, don Pedro dispuso para su esposa Constanza, un primer ordenamiento de su Casa. M. A. Ladero Quesada, "La casa real...”, p. 330.

${ }^{11}$ M. A. Ladero Quesada, "La casa real...", p. 331.

12 Ma Narbona Cárceles, La corte de Carlos III el Noble, $r$ ey de Navarra: espacio doméstico y escenario del poder, 1376-1415, Pamplona, 2006, pp. 59 y 115.

13 "El adelantamiento de Castilla tenialo Ferrand Pérez Puertocarrero, e por ruego de don Juan Núñez de Lara, señor de Vizcaya, diéronlo a Garci Laso de la Vega”. P. LóPEz DE Ayala, Crónica del rey don Pedro, Edición de José Luis Martín, Barcelona, 1991, p. 15.

14 “... avíala Lope Díaz de Almazán, e diéronla a Gutier Ferrández de Toledo”. P. López DE Ayala, Crónica del rey don Pedro..., p. 15.

15 "La escudilla avíala primero Garci Laso, e diéronla a Ferrand Pérez Puertocarrero, a quien avían tirado el adelantamiento de Castilla”. P. López de Ayala, Crónica del rey don Pedro..., p. 16.

16 “... que era primero camarero mayor del rey quando era infante”. P. López de Ayala, Crónica del rey don Pedro..., p. 16.

17 "La repostería tenía Pero Ferrández de Guadalajara e diéronla a Pero Suárez de Toledo el mozo". P. López de Ayala, Crónica del rey don Pedro..., p. 16. 
adelantado de la frontera (infante don Fernando de Aragón) $)^{18}$ y adelantado del reino de Murcia (Fernando de Villena) ${ }^{19}$.

Díaz Martín, apoyándose en la documentación coetánea, matiza aún más y amplía la composición de la Casa de Pedro I y la estructura en adelantados mayores (Castilla, Tierra de León, Galicia y Asturias, reino de Murcia y la Frontera); merino mayor (Galicia); alcaldes del rey, de los fijosdalgo y entregador de la Mesta; alférez mayor; alguacil mayor; almirante mayor de la Mar; ayo del rey; ballestero mayor de rey; caballerizo mayor; canciller mayor; canciller del sello de la poridad; confesores y capellanes; caudillo de los Escuderos del Cuerpo del Rey; cocinero del rey; contadores mayores; copero mayor; despensero mayor; guarda mayor del Cuerpo del Rey; halconero mayor; justicia mayor de la Casa del rey; mayordomo mayor de la Casa del rey; notarios mayores (Castilla, León, Toledo, Andalucía, de latín y de los privilegios rodados); oidores de la Audiencia Real; porteros; pregonero; procurador del rey en la Audiencia; repostero mayor y tesorero mayor ${ }^{20}$.

Sin embargo, y a pesar este aparente orden institucional, algunas fuentes nos inducen a pesar que esta estructura no gozaba aún de una estabilidad plenamente afianzada. Sabemos que los procuradores reunidos en Cortes en Toro en 1371 llegaron a solicitar a Enrique II que organizase la Casa y Corte real tras los estragos de la guerra civil de 1366-1369. El rey respondió que tal ordenamiento ya estaba hecho, refiriéndose, quizá, a la ordenación sobre los derechos de cancillería que había dictado durante aquellos días y cuya intención era acabar con las prácticas abusivas y arbitrarias de los oficiales de las distintas oficinas burocráticas de la Corona en el cobro de los aranceles y tasas cancillerescas. En aquel texto, aún sin ser una ordenanza que regulara la Casa Real en su totalidad, quedaba, sin embargo, perfilada su organización general. Se habla de oficiales, principalmente de carácter doméstico, de la Casa del rey "que no trabajen de jurisdicción": mayordomo mayor, copero mayor, portero mayor, repostero mayor, cocinero, zacatero, caballerizo, cebadero, capellán y aposentador. También de "grandes oficios syn juridiçion de fuera de la casa del rey": alférez, almirante, alfaqueque y monedero; de oficiales "de la casa del rey que han juridiçion e poder para fazer justiçia": cancilleres mayores, notarios mayores, alguacil mayor de la casa del rey y alcaldes de corte; de grandes ofiçios de fuera de la Casa del rey con jurisdicción: alcalde entregador de la Mesta, alcalde mayor de las sacas, adelantado mayor y merino mayor; y, por último, de "ofiçiales que ponen por sy los ofiçiales mayores, asy de la casa del Rey commo fuera della": adelantado mayor y mayordomo mayor ${ }^{21}$.

18 "El adelantamiento de la frontera teníale primero el maestre don Fadrique, e por él Ferrand Enríquez, fijo de don Enrique Enríquez, e diéronle al infante don Fernando de Aragón, marqués de Tortosa, primo del rey". P. López de Ayala, Crónica del rey don Pedro..., p. 16.

19 "E el adelantamiento del regno de Murcia teníale don Ferrando señor de Villena, e quedó con él, caso que dende a pocos días finó el dicho don Ferrando, e dieron el adelantamiento a don Martín Gil, fijo de don Juan Alfonso, señor de Alburquerque”. P. López de Ayala, Crónica del rey don Pedro..., p. 16.

${ }^{20}$ L. V. Díaz Martín, Los of ciales..., pp. 19-118.

${ }^{21}$ Cortes de los antiguos Reinos de León y de Castilla publicadas por la RealAcademia de la Historia. Tomo II, Madrid, 1863, pp. 233-235. También M. A. Ladero Quesada, "La casa real...", p. 328. La misma estructura que en Cortes, con alguna variación, en J. DE SALAZAR y AchA, La casa ..., pp. 134-135. 
Este fue, pues, el modelo, muy similar en sus trazas generales al que presentaba la Casa de Pedro I, sobre el que Juan I se apoyaría cuando en 1385 decidió poner Casa a sus hijos, los infantes Enrique y Fernando ${ }^{22}$. Para la Casa de Enrique el rey dispuso que los oficiales "...de la justiçia, así como adelantamientos, e notarías, e alcaldías de los fijosdalgo, e las otra alcaldías de la nuestra corte...", es decir, los oficiales del aparato burocrático-administrativo de la Corona, fueran los del rey ${ }^{23}$. El resto de oficios quedaron repartidos entre las siguientes personas:

\section{Casa del infante don Enrique (1385) $)^{24}$}

\begin{tabular}{|c|c|}
\hline Of cio & Of ciales \\
\hline Condestable 25 & Alfonso de Aragón, marqués de Villena \\
\hline Canciller mayor $^{26}$ & Juan García Manrique, arzobispo de Santiago \\
\hline Canciller del sello de la poridad & Juan Serrano, prior de Guadalupe \\
\hline Mayordomo & Pedro González de Mendoza ${ }^{27}$ \\
\hline Despensero mayor & Santiago García ${ }^{28}$ \\
\hline Despensero de los caballeros & Juan de San Pedro ${ }^{29}$ \\
\hline Alférez y pendón de la Banda & Pero López Ayala \\
\hline Contador de la despensa & Ferrand Pérez de Villafranca ${ }^{30}$ \\
\hline Alférez mayor & Juan Hurtado de Mendoza \\
\hline Camarero mayor & Juan de Velasco \\
\hline Lugarteniente del camarero mayor & Lope Fernández de Padilla \\
\hline Camarero de la cámara de los paños & Diego López de Estúñiga \\
\hline Alguacil mayor y mariscal & Diego Gómez Sarmiento \\
\hline Repostero & García Fernández Sarmiento \\
\hline Copero & Álvaro de Albornoz \\
\hline Oficial de la escudilla & Juan Duque \\
\hline Oficial del cuchillo o trinchante & Juan Martínez de Medrano \\
\hline Mariscal & Pedro González de Mendoza \\
\hline Aposentador mayor & Pedro González de Mendoza \\
\hline Veedores de las peticiones $^{31}$ & Los doctores Pero López y Pero Sánchez \\
\hline
\end{tabular}

${ }^{22}$ Con anterioridad a esa fecha, sin embargo, el infante Enrique ya dispuso de algunos oficiales en su Casa: Diego Manrique como repostero mayor en 1379; y Juan Martínez de Luna, quien fuera mayordomo mayor de su madre, Leonor de Aragón, como camarermo mayor en 1384. De SALAZAR y Acha, La Casa ..., p. 486; y L. SuÁrez Fernández, Historia del reinado..., II, Documento 73, p. 85.

${ }^{23}$ Todos desempeñaban idénticos oficios en la Casa del rey. P. López de Ayala, Crónica del rey don Juan..., pp. 776-778.

${ }^{24}$ P. López de Ayala, Crónica del rey don Juan..., pp. 776-778 y 785.

${ }^{25}$ Con idéntico oficio en la Casa del rey que lo recibió en Ciudad Rodrigo el 6 de julio de 1382. Publicado por J. De Salazar y Acha, La Casa ..., pp. 570-572.

${ }^{26}$ Con idéntico oficio en la Casa del rey.

${ }^{27}$ Con idéntico oficio en la Casa del rey.

${ }^{28}$ Con idéntico oficio en la Casa del rey.

${ }^{29}$ Con idéntico oficio en la Casa del rey.

${ }^{30}$ Algunos datos biográficos más de este oficial en R. SÁnchez SAus, Las élites..., pp. 95-96 y 125.

31 "E aunque el dicho infante non seda de edad para oír peticiones, que éstos usen de sus oficios con los tutores e regidores del regno, fasta quel dicho infante haya edad porque tenga sus registros, e toda 
Por su parte, la Casa del infante Fernando, en calidad de segundo heredero, fue menor en cuanto a la cuantía de sus oficiales quedando integrada, al menos en un primer momento, por los siguientes oficios:

Casa del infante don Fernando (1385) ${ }^{32}$

\begin{tabular}{|c|c|}
\hline Of cio & Of ciales \\
\hline Mayordomo mayor & $\begin{array}{l}\text { Pero Suárez de Quiñones } \\
\text { Juan Alfonso de la Cerda }\end{array}$ \\
\hline Canciller mayor & el arcediano de Treviño \\
\hline Camarero mayor & Juan Núñez de Villaizán \\
\hline Alférez mayor & Carlos Ramírez de Arellano \\
\hline Copero mayor & Mosén Manuel de Villanoba \\
\hline Repostero mayor & Lope Fernández de Vega \\
\hline Alguacil mayor & Ferrand Carrillo ${ }^{33}$ \\
\hline Oficial del cuchillo o trinchante & Álvaro de Villaizán \\
\hline Oficial de la escudilla & el hijo de Lope Fernández de Vega \\
\hline Contador mayor & Diego Gutiérrez \\
\hline Repostero mayor & Alfonso García de Madrid \\
\hline
\end{tabular}

Sin embargo, y a pesar de la solidez institucional de la estructura de la Casa Real durante la década de 1380, Juan I mostró desde los primeros años de su reinado una preocupación por perfeccionarla y consolidarla, una acción, sin duda, emparejada con las otras reformas llevadas a cabo por el monarca en su ardua labor de afianzamiento y fortalecimiento del poder real de la nueva dinastía Trastámara. Los problemas que presentaba la organización burocrático-administrativo de la monarquía eran, desde luego, evidentes: carencia de una organización racional en los cuadros administrativos de la propia Corona castellana, la inexistencia de competencias determinadas para cada oficial áulico y duplicidad de funciones y obligaciones, entre otros aspectos, hacían de la corte un caos administrativo en el que su buen funcionamiento quedaba en manos de una élite de oficiales que, a falta de un marco legislativo concreto y bien definido, fue la encargada de gestionar los negocios de la monarquía, casi siempre con éxito. Ahí están los ejemplos del doctor Alvar Martínez de Villarreal en tiempos de Juan I, el canciller Juan Martínez en época de Enrique III o el doctor Fernando Díaz de Toledo durante el reinado de Juan II.

En este empeño de modernización, Juan I de Castilla pensó en importar el exitoso modelo aragonés de la Ordinacions (1344) de su suegro, Pedro IV. Consta que en

aquella ordenanza que nos ordenamos quando establecimos estos oficiales". P. LóPEz DE AyALA, Crónica del rey don Juan..., p. 777.

${ }^{32}$ P. López de Ayala, Crónica del rey don Juan ..., pp. 776-778 y 785.

${ }^{33}$ Hijo del camarero real Juan Carrillo. 
1384 encargó una copia ${ }^{34}$ y que el texto se encontraba en Castilla en $1387^{35}$; parece, pues, que hubo intenciones serias de materializarlo, pero la prematura muerte del rey en 1390 y la difícil minoría de Enrique III con la consiguiente pérdida de una autoridad monárquica fuerte hicieron imposible su implantación. De forma paralela a la llegada del texto de las Ordinacions a Castilla se produjeron algunos movimientos reformadores en el seno de la Casa Real. Sabemos que las Cortes de Briviesca en 1387 insistieron al rey en la necesidad de reformar algunos aspectos de su Casa, sobre todo en lo relativo a los elevados gastos de un personal en constante crecimiento y, según los procuradores, en algunos casos poco rentable para la Corona. La medida era, desde luego, trascendental pues pretendía cortar de raíz un problema que por su envergadura y el consiguiente colapso de la Hacienda Real impedía que muchos oficiales recibieran a tiempo sus raciones y quitaciones o, simplemente, que no las recibieran. Consciente del problema, Juan I accedió a las protestas de los procuradores y ordenó revisar, con el asesoramiento técnico del Consejo Real, todas las mercedes que se concedieran en lo sucesivo ${ }^{36}$, aunque, como bien sabemos, la medida debió de ser poco efectiva si tenemos en cuenta que más de medio siglo después, en 1442, los procuradores de Cortes reunidos en Valladolid incidían ante Juan II con problemas muy similares ${ }^{37}$.

Mención aparte, merece el elevado número de oficiales que servían entonces al monarca, pues más allá de la prodigalidad regia criticada por las Cortes, ello respondía, en realidad, a las crecientes necesidades burocrático-administrativas y políticas de una monarquía en pleno proceso de afianzamiento institucional. Por una parte, el nacimiento en 1385 del Consejo Real y el desarrollo asociado de la Audiencia Real con sus respectivas maquinarias burocráticas precisaba de numerosos oficiales cualificados $\mathrm{y}$, por lo tanto, bien pagados ${ }^{38}$; por otra, la consolidación de las diferentes cámaras regias, documentadas por vez primera en tiempos de Juan I, como consecuencia del incremento de los ajuares de una realeza cada vez más preocupada por mostrar una imagen esplendorosa en consonancia con sus aspiraciones políticas de fortaleza y majestad, elevaron el número de los servidores áulicos a límites no conocidos hasta entonces con la consiguiente queja de los procuradores que veían en ello un aumento constante de la presión fiscal sobre los pecheros.

Al final del reinado, y pese a las dificultades ya mencionadas, las reformas protagonizadas por el rey habían tenido éxito. La Casa Real, así como la estructura de todo el aparato burocrático-administrativo de la Corona, habían experimentado un notable desarrollo institucional de manera que, en sus líneas básicas, era idéntico al que los sucesores de Juan I tenían un siglo más tarde.

${ }^{34}$ El día 5 de febrero de 1384 Pedro IV dio orden de traer el pergamino para hacer la copia. ACA, Registro 1.287, fol. 2r. Citado por L. SuÁrez Fernández, Historia del reinado..., I, p. 315.

${ }^{35} \mathrm{M}^{\mathrm{a}}$ Narbona Cárceles, La corte..., p. 55.

${ }^{36}$ Cortes..., II, pp. 359 y siguientes.

${ }^{37}$ Cortes, III, pp. 422-427.

${ }^{38}$ Sobre los orígenes del Consejo Real de Castilla véase S. DE Dios, El Consejo Real de Castilla (1385-1522), Madrid, 1982, en especial las pp. 63-103. 


\section{LA CASA DE JUAN I}

\subsection{LOS MAYORDOMOS}

Al frente de todo el funcionamiento de la Casa Real estaba la figura del mayordomo mayor. Bajo su responsabilidad recaía el nombramiento de muchos oficiales menores, presidir las comidas del monarca ${ }^{39}$ y asistir a actos solemnes como juras, firmas de paces o capitulaciones matrimoniales ${ }^{40}$, además, claro está, de ocuparse de la administración del patrimonio regio, labor, ésta, en la que resultaba esencial el apoyo del veedor de la Casa del rey, un oficial encargado de informar y asesorar al mayordomo y al camarero sobre los precios de las provisiones necesarias para la Casa y la cámara reales y cuyo ejercicio por su dificultad técnica parece que recayó sobre oficiales altamente cualificados ${ }^{41}$.

El acceso al oficio de mayordomo mayor estaba reservado a las personalidades más relevantes de la corte. Durante el siglo XIII y la primera mitad del XIV el cargo estuvo ostentado, incluso, por varios miembros de la propia Familia Real, entre ellos el infante don Sancho (1276-1277), don Manuel de Castilla (1278-1282), el infante don Juan de Castilla (1284-1285) o el infante don Pedro de Castilla (1310-1311), entre otros linajudos personajes del entorno áulico ${ }^{42}$. La llegada al trono de los Trastámara no supuso, en líneas generales, un cambio con respecto a etapas anteriores, si bien es cierto que el cargo no volvió a recaer en ningún miembro de la realeza para pasar a ser desempeñado desde entonces por nobles de confianza del rey que, de esta manera, premiaba fidelidades y servicios a la Corona en los años difíciles de la instauración de la nueva dinastía en tierras de Castilla. El nombramiento de mayordomos reales era, pues, una cuestión delicada en la que intervenía el propio monarca. Por ello, y con la intención de evitar desagradables su acceso quedó regulado de manera muy precisa tras la llegada de los Trastámaras al trono castellano. Los judíos fueron rápidamente excluidos de los posibles candidatos ${ }^{43}$ y no tardaron en fijarse los aran-

39 J. DE SALAZAR y Acha, La casa ..., pp. 178-179.

${ }^{40}$ Desempeñando estas funciones nos encontramos, por ejemplo, a Juan Martínez de Luna, mayordomo mayor de la infanta Leonor de Aragón, Pedro González de Mendoza, mayordomo mayor del infante don Juan, y al camarero mayor del infante, Juan Carrillo, durante la firma de la confirmación de las paces entre Castilla y Aragón en junio de 1375 en Soria y Almazán. ACA, Registro 1.543, fols. $158 \mathrm{r}-170 \mathrm{v}$.

${ }^{41}$ En febrero de 1388 lo ostentaba Pero Sánchez de Castillo, por entonces oidor de la Audiencia Real y doctor en leyes, y más tarde doctor, contador mayor de Enrique III y contador de la Casa del rey en San Felices de Gállegos. AGN, Comptos, Carp. 57, nº 11. También en F. de P. Cañas Gálvez, Burocracia y cancillería... (en prensa).

${ }^{42}$ Como don Juan Fernández cabellos de oro, Ruy Pérez Ponce, Rodrigo Rodríguez Carrillo o Juan Núñez de Lara. J. de Salazar y Acha, La casa..., pp. 380-382.

${ }^{43}$ En las Cortes de Burgos de 1367 Enrique II ya les había prohibido acceder a un puesto en el Consejo Real. La prohibición se amplió en las Cortes de Burgos de 1377 a todos los oficios de las Casas “... del Rey, de la Reina, de los Infantes, prelados, caballeros u otras personas, de suerte que no pudiesen tener oficio alguno en la corte ni al servicio de los particulares, sobre todo el de almojarife, siempre odioso a los cristianos". Juan I fue más allá impidiéndoles que pudieran ejercer oficios relacionados con la administración de las rentas públicas. Cortes..., II, pp.151, 282 y 310. 
celes que los recién nombrados mayordomos deberían pagar a la Cancillería Real. Tanto el alférez real como el mayordomo pagarían 1.800 maravedíes y 120 cuando nombrara el mayordomo a su lugarteniente ${ }^{44}$.

Además, el oficio adquirió durante estos años finales del siglo XIV carácter hereditario al recaer en los Mendoza, uno de los linajes encumbrados por Enrique II tras su llegada al trono castellano. Primero fue Pedro González de Mendoza, señor de Hita, Buitrago, Torija y del Real de Manzanares, quien desempeñó la mayordomía de Juan I desde su etapa como infante heredero (1374), aunque ya servía a Enrique II con este mismo oficio desde 1367, hasta su fallecimiento en la batalla de Aljubarrota (1385); después su hijo, Diego Hurtado de Mendoza (1385-1389), que fue nombrado mayordomo mayor "aun siendo menor de edad..., cuyo empleo fue preciso lo sirviera interinamente su tio y tutor, don Juan Hurtado de Mendoza, señor de Mendívil y Almazán, ricohombre de sangre, quien después no lo quiso dejar y en su lugar le hizo el rey Justicia Mayor de Castilla..." "45; más tarde el mencionado Juan Hurtado de Mendoza (1391-†1419) y durante el siglo xv, y hasta el nombramiento de Juan Pacheco, primero como mayordomo del príncipe don Enrique (1440) y más tarde del rey Enrique IV (1454), ostentaron el oficio Juan Hurtado de Mendoza (1419- $\uparrow 1426)$ y Ruy Díaz de Mendoza (1426-1454) ${ }^{46}$. En octubre de 1379 Fernando Díaz de Mendoza aparece como mayordomo y vasallo de Juan I. Probablemente se trataba de un mayordomo menor o de un lugarteniente del mayordomo mayor, con quien, sin duda, estaba emparentado ${ }^{47}$.

Pero, si como acabamos de comprobar, la llegada a la mayordomía era la recompensa regia a la fidelidad de algunos nobles, su ejercicio también se convirtió, por razones evidentes, en una puerta abierta para acceder a otros relevantes e influyentes cargos cortesanos y, por lo tanto, a una posición económica desahogada para sus titulares. Sabemos, por ejemplo, que tanto Juan Hurtado de Mendoza (1385) como su sobrino Diego Hurtado de Mendoza (1392) fueron también mayordomos del príncipe don Enrique, y que Juan fue consejero real (1387-1388) además de tutor y ayo de Enrique III. Con anterioridad a su llegada a la mayordomía real había desempeñado los oficios de prestamero mayor de Vizcaya $(1375)^{48}$ y alférez mayor de Enrique II y Juan I (1372-1385) ${ }^{49}$. Otros Mendozas tuvieron, al parecer oficios cortesanos menos

${ }^{44}$ Cortes..., II, pp. 222, 223, 233 y 235.

45 D. Gutiérrez Coronel, Historia Genealógica de la Casa de Mendoza , Cuenca, 1946, p. 160. Citado por J. De Salazar y Acha, La casa..., p. 391.

46 J. De Salazar y Acha, La casa..., pp. 390-393.

${ }^{47}$ RAH, Salazar, M-10, fol. 199v.

${ }^{48}$ Como tal aparece en una carta del infante don Juan confirmando el acta de fundación y aforamiento de la villa de Elorrio dada por don Tello y su esposa, doña Juana en Bilbao el 27 de junio de 1356. Toro, diciembre de 1375. La carta fue más tarde confirmada por Enrique III, Juan II y Enrique IV. J. Enríquez Fernández, C. Hidalgo De Cisneros y A. Martinéz Lahidalga, Archivo foral de Vizcaya. Sección judicial. Documentación medieval (1284-1520), San Sebastián, 2005, Documento 45, pp. 125 132.

49 J. de Salazar y Acha, La casa..., p. 440. 
destacados pero igualmente influyentes. Así ocurrió, por ejemplo, con Pedro Hurtado de Mendoza que en 1384 figuraba como oidor de la Audiencia Real ${ }^{50}$.

En lo referente a las ventajas económicas derivadas del ejercicio de la mayordomía, los datos hablan por sí solos. Por una parte estaban los elevados aranceles cancillerescos por el desempeño del oficio ${ }^{51}$, cuya cuantía había sido regulada por Enrique II. La ley, incumplida sistemáticamente, fue de nuevo fijada por Juan II en Segovia el 20 de diciembre de 1433. Se volvió a insistir entonces en que se obedecieran en el apartado referente a mayordomos y sus lugartenientes "las leyes fechas por el dicho rey don Enrrique, mi visahuelo" instando a que estos oficiales no cobraran más de lo dispuesto, y señalando que "de lo que el mayordomo mayor libre o su lugarteniente que los ayan e lieven cada uno de los otros contadores mayores, e esto de aquellas cosas que lo acostunbro levar fasta aquí el mayordomo mayor o su lugarteniente e non de otras algunas ni mas ni allende so las penas suso puestas contra los dichos mis contadores mayores e sus ofiçiales". La misma ordenanza, inspirándose en las cantidades tomadas por Enrique II, determinaba también que el "mayordomo mayor ó su lugarteniente lieve de asentamiento de cada racion nueva un dia de racion é de cada fe que libre doce maravedis é de asentamiento de cada libramiento tres maravedis segund que fasta aquí é non que non ayan nin lieven mas nin otra cosa alguna por razon del dicho ofiçio"ss.

Por otro lado, y junto a estos derechos arancelarios, estaban las mercedes regias recibidas gracias a la estrecha relación diaria con el rey. En octubre de 1379 sabemos que Juan I concedió al mayordomo Fernando Díaz de Mendoza 40 excusados "quitos e francos" en Villalquite, en la merindad de Monzón, una cantidad que fue sucesivamente confirmada a sus herederos hasta tiempos de los Reyes Católicos ${ }^{53}$. Y poco tiempo antes, en agosto de ese mismo año, el rey ratificó al mayordomo mayor Pedro González de Mendoza 140 excusados que se le situaron en el arzobispado de Toledo (120) y obispado de Sigüenza (20) ${ }^{54}$. Por aquellos mismos días, el rey le confirmó también la exención de tributos concedida por Pedro I a todos los hombres

${ }^{50}$ Como tal dictó, junto a don Pedro Tenorio, arzobispo de Toledo, una sentencia, sobre la irregularidad de la venta realizada por el concejo de Ávila del lugar de Iruelas. Madrigal de las Altas Torres, 30 de septiembre de 1384. Publicado por A. Barrios García, B. Casado Quintanilla, C. Luis López y G. Del Ser Quijano, Documentación medieval del Archivo Municipal de Ávila (1256-1474), Ávila, 1988, Documento 23, pp. 59-60.

${ }^{51}$ Desconocemos con precisión la cuantía total de esos importes en tiempos de Juan I pero debían de ser elevados si tenemos en cuenta que en 1431 eran para cancilleres mayores, mayordomos mayores y notarios mayores de 98.400 maravedíes y de 49.200 para cancilleres, mayordomos y notarios menores. AGS, DC, Leg. 3, fol. 82. M. A. LAdERo Quesada, La Hacienda Real de Castilla en el siglo XV, La Laguna, 1973, p. 18, nota ${ }^{\circ} 3$.

${ }^{52}$ BN, Ms. 9.427. AGS, AGS, EMR, Leg. 3, fol. 1. AGS, DC, Leg. 3, fol. 1. RAH, Memorias de don Enrique IV de Castilla, II, Madrid, 1835-1913, pp. 474 y siguientes. J. Abellán Pérez, Documentos de Juan II, Murcia-Cádiz, 1988, Documento 180.

${ }_{53}$ Por albalá de 6 de octubre de 1379. Confirmado por Enrique III (1401) y los Reyes Católicos (1480). RAH, Salazar, M-10, fol. 199v.

${ }^{54}$ Por albalá de 12 de agosto de 1379. AHN, Nobleza, Osuna, Carp. 173, nº 19. 
que González de Mendoza tenía a su servicio ${ }^{55}$ y le ratificaba, entre una larga lista de concesiones de diversa índole e importancia, sendos mayorazgos fundados a favor de su hijo primogénito (1380) ${ }^{56}$ y su otro hijo, Juan Hurtado de Mendoza (1382) ${ }^{57}$.

La dignidad de mayordomo llevaba aparejada, por último, un lugar preferente en los séquitos regios y en los lugares de aposentamiento de la corte. Consta que en los primeros años del reinado de Juan II los mayordomos ocupaban durante sus viajes cerca del rey una posada grande y sus lugartenientes dos posadas pequeñas mientras que "su compañía" disponía de tres posadas pequeñas ${ }^{58}$.

\subsection{LA CÁMARA REGIA. ORGANIZACIÓN Y ECONOMÍA}

Era el ámbito más privado y recogido en la cotidianidad de la persona regia ${ }^{59}$. Su gobierno y funcionamiento estaba encomendado al camarero mayor, oficial palatino de alto rango sobre el que también recaía el control de los aposentos del monarca y de todo lo que en ellos había: vestiduras, lecho, arcas, joyas, armas, telas y escrituras, además del dinero que de allí entraba y salía. Bajo su autoridad quedaban varios camareros menores y un número indeterminado de oficiales cuyo perfil y competencias trataremos a lo largo de este trabajo ${ }^{60}$.

La evolución institucional de la cámara regia a lo largo del siglo XIV fue paralela a la experimentada por la mayordomía real en aquellos años. En este sentido, es necesario resaltar que el reinado de Alfonso XI marcó el inicio de una nueva etapa caracterizada por una creciente autonomía de los camareros con respecto a los mayordomos. La llegada al trono de los Trastámara no hizo sino consolidar aquella tendencia. La medida adoptada por Enrique II en las Cortes de Toro de 1371 de confirmar a la cámara los cuatro escribanos nombrados por Fernando IV en 1312 venía, en cierto modo, a consolidar definitivamente el creciente auge institucional de la cámara regia como espacio administrativo propio y dotado cada vez más de mayores competencias burocráticas en el seno de la Casa Real ${ }^{61}$.

Es en estos años del reinado de Juan I cuando la cámara regia adquiere la carta de naturaleza institucional y burocrática que le va a caracterizar durante toda la Baja Edad Media. Por una parte, asistimos, como ya había ocurrido con la mayordomía,

55 Yugueros, hortelanos, molineros, pastores, apaniaguados, acemileros, horneros, amos y mayordomos. Por carta de privilegio dada en las Cortes de Burgos el 20 de agosto de 1379. AHN, Nobleza, Osuna, Carp. 1.652, nº 7. L. SuÁrez Fernández, Historia del reinado..., II, Documento 58, pp. 64-66.

${ }^{56}$ Por privilegio rodado fechado en Toledo el 10 de febrero de 1380 que, a su vez, recoge, la carta fundacional del mayorazgo dada en Guadalajara el 13 de enero de 1380. AHN, Nobleza, Osuna, Carp. $14, n^{\circ} 10$.

${ }^{57}$ Segovia, 5 de julio de 1382. AHN, Nobleza, Osuna, Carp. 174, nº 2. Una relación detallada de las mercedes en A. I. SÁnchez Prieto, La Casa de Mendoza hasta el tercer duque del Infantado (13501531). El ejercicio y alcance del poder señorial en la Castilla bajomedieval Madrid, 2001, p. 36, notas $\mathrm{n}^{\mathrm{o}} 70$ y 71 .

${ }^{58}$ AHN, Códices, 1.369B, fol. 14. Citado por F. de P. Cañas Gálvez, El itinerario..., p. 54, nota $\mathrm{n}^{\circ} 190$.

${ }^{59}$ F. de P. CAÑas Gálvez, "La cámara...”, pp. 81-195.

${ }^{60}$ J. de Salazar y Acha, La casa ..., pp. 253-253.

${ }^{61}$ Cortes, II, p. 195. 
a la patrimonialización del oficio de camarero mayor del rey, en este caso en la Casa de Velasco, otro de los linajes encumbrados por la realeza Trastámara ${ }^{62}$. Lo mismo sucedió en la cámara de la jineta, que después de una primera etapa bajo el control de Domingo Fernández (1380), posteriormente pasó a manos de Juan de Velasco y en 1419 a su hermano, Fernando de Velasco ${ }^{63}$. No ocurrió lo mismo con la titularidad de la cámara de los paños ${ }^{64}$ ni tampoco con la de las reinas consortes ${ }^{65}$ y el infante heredero ${ }^{66}$ que no quedaron vinculadas a ninguna familia en concreto.

Por otro lado, asistimos en este tiempo a la consolidación definitiva de la subdivisión que había experimentado la cámara real en otras dos cámaras menores, la de los paños y la de la jineta, como consecuencia de unos ajuares regios más numerosos y suntuosos en perfecta consonancia con una realeza en pleno desarrollo del fortalecimiento de su poder político. Los datos hablan por sí solos y si en noviembre de 1379 fueron necesarias siete acémilas para llevar desde Burgos a Valladolid "algunas arcas de la nuestra cámara (del rey)" ${ }^{\prime 67}$ en octubre de 1397 para el traslado de toda la cámara de Enrique III desde Ávila a San Martín de Valdeiglesias se precisaron ya nueve de estas acémilas ${ }^{68}$. Lejos quedan, comparados con estas cifras, las cuatro acémilas que en la primavera de 1383 transportaron vestidos y otros objetos de la cámara del infante don Carlos de Navarra desde Pamplona a Badajoz para asistir allí a la boda del rey de Castilla ${ }^{69}$.

Las cuantías de maravedíes manejadas por los oficiales de la cámara, similares a las manejadas en tiempos de Juan II ${ }^{70}$, rubrican el creciente peso económico e institucional de este ámbito palaciego. Las cuentas de López de Estúñiga nos aseguran que a finales de 1380 se habían recibido en la cámara real cerca de 6.500 .00 de maravedíes de los que se gastaron poco más de 424.000, sin contar los pagos realizados por

${ }^{62}$ Pedro Fernández de Velasco fue nombrado camarero mayor de Enrique II por carta real de merced del 20 de abril de 1370. Esta familia mantuvo la dignidad durante la Baja Edad Media y la Edad Moderna. J. DE SAlAzAR y Acha, La casa ..., p. 480.

${ }^{63}$ AHN, Nobleza, Osuna, Carp. 40, no 1; y J. DE SAlazAr y Acha, La casa ..., p. 488.

${ }^{64}$ En 1385 Diego López de Estúñiga fue designado camarero de la cámara de los paños del infante don Enrique. Una vez en el trono, Enrique III concedió a Ruy López de Ávalos esta cámara (13901423). J. Salazar y Acha, La Casa..., p. 483.

${ }^{65}$ Tan sólo nos consta el nombre de dos camareras al servicio de Beatriz de Portugal: Inés Martínez de Tavera y Juana Martínez de Leyva. C. Olivera Serrano, Beatriz de Portugal. La pugna dinástica Avís-Trastámara. Santiago de Compostela 2005, 222-229.

${ }^{66}$ Fueron camareros mayores del infante don Enrique, Juan Martínez de Luna (1384), antiguo camarero de su madre, Leonor de Aragón, y más tarde Juan Hurtado de Mendoza (1392).

${ }^{67}$ El alquiler de cada acémila costó entonces seis maravedíes diarios (cuatro para la ida y dos para "la tornada"). El precio de compra una de estas acémilas era de 1.050 maravedíes. Cantidades pagadas por albalaes del rey de 16 de noviembre de 1379 y 3 de abril de 1380. AHN, Nobleza, Osuna, Carp. $40, \mathrm{n}^{\mathrm{o}} 1$.

${ }^{68}$ AGS, PR, Leg. 29, fol. 28. F. de P. CaÑas Gálvez, “La cámara de Juan II...”, p. 95.

${ }^{69}$ AGN, Comptos, Registro 172, fol. 40v.

70 Entre 4.000 .000 y 5.000.000 de maravedíes a mediados del siglo XV. F. de P. CAÑas Gálvez, "La cámara...", p. 92-102. 
el tesorero Miguel Ruiz que tuvieron que ser revisados en la corte "porque tiene mas maravedis pagados que quentos avia dado en cuenta a esta saçon"’’1.

Asimismo, el elevado número de oficiales adscritos a la cámara evidencia su preponderancia burocrática-administrativa. Una vez más y gracias a las cuentas del camarero Diego López de Estúñiga sabemos que en los años finales de Enrique II y los primeros de Juan I bajo la autoridad del camarero mayor había dos contadores mayores $^{72}$, cuatro tesoreros mayores ${ }^{73}$, una veintena de $\operatorname{arrendadores}^{74}, \mathrm{y}$, aunque no se citan en esta fuente, los cuatro, o más, escribanos de cámara ya señalados ${ }^{75}$, un número indeterminado de secretarios ${ }^{76}$, oficiales, estos últimos, que a lo largo del siglo $\mathrm{XV}$ irían ganando lenta, pero inexorablemente, terreno institucional a los citados escribanos de cámara, un canciller del sello de la poridad ${ }^{77}$, uno o dos contadores y, quizá, un escribano de las cámaras, cuya actividad, sin embargo, queda contrastada desde tiempos de Enrique III y Juan II $^{78}$. A ellos habría que añadir oficiales encargados

${ }^{71}$ AHN, Nobleza, Osuna, Carp. 40, no 1 . Publicado por L. SuÁrez Fernández, Historia del reinado..., II, Documento 181, pp. 250-255.

${ }_{72}$ Ruy Pérez Esquivel y Alfonso Sanchez del Castillo.

73 Toledo: Gómez García; Merindades de Castilla con los obispados de Ávila y Segovia: Diego Fernández de Villegas; Reino de Galicia: Juan Núñez; y Andalucía: Miguel Ruiz.

${ }^{74}$ Arzobispado de Toledo: Pero García de Peñaranda; obispado de Plasencia y Coria: Alvar Gil de Cáceres; obispado de Segovia: Velasco Vela de Cuéllar; obispado de Salamanca y Ciudad Rodrigo: Diego García de Toro; obispado de Palencia: Pero Fernández Sancho; cuatro sacadas de Asturias de Oviedo; Alvar Sánchez de Castellanos; obispado de Zamora: Ferrant Sánchez Gallego; obispado de León y Astorga: Sancho Pérez de León; obispado de Ávila: Diego Gómez; obispado de Burgos: Pero Fernández de Villegas; obispado de Calahorra: Juan García de Camargo; obispado de Cuenca: Juan Martínez de Cuenca; obispado de Sigüenza: Domingo Fernández del Castillo; obispado de Osma: Pero Fernández de Castro; reino de Galicia: García Alfonso de Sahagún; aljama de los judíos de Palencia: Alvar Núñez; aljama de los judíos de Toledo: Domingo Fernández; aljama de los reinos de León y Galicia: Alvar Alfonso de León; y chancillería: Antón Martínez de Córdoba.

${ }^{75}$ Este número fue en aumento a lo largo del reinado de Juan I. En 1387, por ejemplo, eran ocho los escribanos de cámara documentados (Nicolás Fernández, Diego García, Alfonso González, Juan López, Ruy López, Juan Martínez, Alfonso Ruiz y Juan Sánchez); y en 1390 lo eran siete (Pero Alfonso, Gutierre Díaz, Diego García, Juan García, Ruy López, Juan Martínez y Bartolomé Rodríguez).

${ }^{76}$ El nombre de los primeros secretarios que conocemos en la corte de Castilla son: Diego Pérez y Pedro Sánchez de Torres, ambos secretarios de Enrique II en 1375, y Marcos Alfonso y Juan Fernández de Juan I en 1386.

77 Ostentaron este oficio Juan Serrano, prior de Guadalupe, entre 1385 y 1390, y Juan Martínez entre 1389 y 1409. Con anterioridad este último oficial había sido escribano del rey (1380-1389), escribano de cámara (1385-1389) y escribano del Consejo Real (1386). F. de P. CAÑAS GÁlvez, Burocracia y cancillería en la corte de Juan II de Castilla (1406-1454). Estudio institucional y prosopográf co (en prensa).

${ }^{78}$ F. de P. Cañas Gálvez, “La cámara...”, pp. 97-101. 
de su limpieza ${ }^{79}$, pajes ${ }^{80}$, donceles ${ }^{81}$ y un importante número de personas destinadas a controlar su acceso y garantizar la seguridad del rey: porteros $^{82}$, guardas ${ }^{83}$ y guardas mayores, ballesteros ${ }^{84}$, ballesteros mayores y alféreces de los ballesteros ${ }^{85}$, escuderos y un caudillo mayor de los escuderos, además de los Monteros de Espinosa cuyo principal cometido consistía, como es bien sabido, en vigilar el sueño del monarca ${ }^{86}$.

\subsubsection{CAMAREROS MAYORES}

Como ya se ha señalado el camarero mayor era el responsable máximo del funcionamiento de la cámara. Sin embargo, y de igual modo que una parte sustancial de las dignidades curiales, el oficio había adquirido a finales del siglo XIV un carácter puramente honorífico y la participación de sus titulares quedaba reservada únicamente a los grandes acontecimientos cortesanos en los que solía figurar como testigo, según ya vimos, junto a otros destacados servidores regios.

${ }^{79}$ Con el oficio de barrendera figura al servicio de Juan I en diciembre de 1379 Juana Martínez. Por albalá de 18 de diciembre de 1379. AHN, Nobleza, Osuna, Carp. 40, $\mathrm{n}^{\circ} 1$.

${ }^{80}$ Las noticias sobre estos oficiales son muy escasas durante el reinado de Juan I. Sabemos que en abril de 1384 el infante don Carlos de Navarra había recibido en el Sitio de Lisboa a tres pajes del rey de Castilla que le habían llevado en nombre de dicho rey "dos sommiers" y ciertas tiendas y pabellones". Por ello, el infante navarro les había concedido 120 maravedíes de merced. Sitio de Lisboa, 29 de abril de 1384. J. R. Castro, Catálogo..., Tomo XV, Documento 238, pp. 107-108.

${ }^{81}$ Por doncel de Juan I, Juan Álvarez gozaba a principios de 1380 de una ración diaria de 6 maravedíes. Librados por albalá de 8 de enero de 1380. AHN, Nobleza, Osuna, Carp. 40, nº 1.

${ }^{82}$ Desde, al menos, 1375 el infante Juan dispuso de un portero que custodiaba el acceso a su Casa o cámara llamado Pedro García. En aquella misma fecha, este oficial también despeñaba el oficio de pregonero del infante. Todavía vivía en 1406, momento en el que recibió de Enrique III una merced de 50 maravedíes. En 1385 era portero de la Casa del rey Alfonso García. AGS, DC, Leg. 4, fol. 32. L. Pascual Martínez, Documentos de Enrique II, Murcia, 1983, Documento CLXXVII, pp. 283-284.

${ }^{83}$ Por su labor, los guardas reales percibían a principios de este reinado una ración diaria de 12 maravedíes que sumaban 1.800 por tercio. Así consta en el caso del guarda Pero Ordóñez de Encinas en 1380. Por albalá de 8 de enero de 1380. AHN, Nobleza, Osuna, Carp. 40, $n^{\circ} 1$.

${ }^{84}$ Las raciones percibidas por los ballesteros reales variaron económicamente de unos oficiales a otros yendo de los 5 maravedíes diarios de Alfonso Fernández de Palencia a los 6 de Ruy Fernández de Becerril o los 7 de Ferrant Álvarez de Sevilla y Ferrant Fernández de Castroverde, todos en 1380. AHN, Nobleza, Osuna, Carp. 40, $\mathrm{n}^{\circ} 1$.

${ }^{85}$ Don Juan ya contaba en su Casa con este oficial siendo aún infante heredero. El oficio era ostentado en abril de 1379 por Alfonso Fernández de Villalpando. Véase carta del infante al concejo de Burgos ordenando enviar sueldo de quince días para los 100 ballesteros que sirven en la guerra con el rey de Navarra. Calahorra, 19 de abril de 1379. AM, Burgos, Libros de Actas, 1389, fol. 57v. F. SuÁrez FERnÁndez, Historia del reinado.... II, Documento 9, pp. 25-26.

${ }^{86}$ Confirmando anteriores órdenes de Alfonso XI y Enrique II, en las Cortes de Burgos de 1379 Juan I había dispuesto en relación a los Monteros de Espinosa que “... quando acaesçe que nos entramos en alguna çibdat o villa o lugar de nuestros regnos, los nuestros ofiçiales demandan muchas cosas desaguisadas... que no den cosa alguna a ofiçiales algunos nuestros por derechos que demanden, salvo que los judios del lugar... den a los monteros de Espinosa doze maraveids por cada atora e que ello que aguarden los judios que non resçiban mal, nin daño, nin desaguisado”. J. M. DíEz Martínez, A. Bejarano y A. L. Molina Molina, Documentos..., Documento 5, pp. 7-9. 
Era, por lo tanto, un oficio de la máxima cercanía al rey y reservado a oficiales de gran prestigio y lealtad y, en este caso, a los que la dinastía Trastámara quiso premiar su fidelidad durante su lucha por el trono castellano. Entre las obligaciones administrativas de estos camareros figuraban las de ordenar el pago de las raciones y quitaciones de los oficiales de la Casa del rey ${ }^{87}$, obligación compartida, en ocasiones, con los despenseros, y encargar, a su vez, a los camareros menores y despenseros regios, y bajo la supervisión del veedor de la Casa del rey, librar determinadas cantidades a mensajeros extranjeros ${ }^{88}$, a diversos mercaderes por la compra ${ }^{89}$ y el tinte de telas ${ }^{90} \mathrm{o}$ por la adquisición de otras necesidades para la cámara ${ }^{91}$. Como en el caso de los mayordomos, los camareros ocupaban un lugar destacado en los cortejos regios. Para su aposentamiento se destinaba una posada grandes, otras dos posadas grandes iban a sus lugartenientes y una pequeña para su "compañía"

El cargo también era, como en el caso de los mayordomos, una vía de consolidación social y de enriquecimiento personal importante. Diego López de Estúñiga, camarero de Juan I desde su etapa como infante heredero (1377) llegaría años más tarde a ostentar el señorío de Moral de la Reina, Capilla, Valdaragón y El Bodón (1382) y los cargos de alguacil y justicia mayor de Enrique III (1392-1414) ${ }^{93}$. Más notable es el caso del camarero mayor Pedro Fernández de Velasco, quien tras su nombramiento en $1374^{94}$ llegó a recibir del rey los señoríos de Briviesca (1379), Herrera del Pisuerga (1379) y los valles de Ruesga, Soba y Puebla de Arganzón en

${ }^{87}$ Por albalá del rey de 4 de febrero de 1380 sabemos que López de Estúñiga ordenó el pago de los 2.500 maravedíes de ración anual de Ferrant Álvarez de Sevilla por ballestero de Juan I. AHN, Nobleza, Osuna, Carp. 40, n ${ }^{\circ} 1$.

${ }^{88}$ Por albalá de 20 de octubre de 1379 el camarero Alfonso Ruiz recibió 15.000 maravedíes ““"para dar a los moros mensajeros del rey de Granada que vinieron a nos (al Rey) a Burgos con el presente". AHN, Nobleza, Osuna, Carp. 40, $\mathrm{n}^{\mathrm{o}} 1$.

${ }^{89}$ En junio de 1380 el camarero Ruy Fernández recibió un total de 1.951 doblas de oro moriscas por la compra de "paños de oro e sede e de otras cosas en Granada". Por albalá de 8 de junio de 1380. AHN, Nobleza, Osuna, Carp. 40, $\mathrm{n}^{\mathrm{o}} 1$.

${ }^{90}$ Por albalá del rey de 11 de febrero de 1380 el camarero Gonzalo Rodríguez recibió del camarero Diego López de Estúñiga 73 maravedíes y cinco dineros "para tondir honse varas de escarlata e de treynta e ocho varas de villaforda, a rason de a quinse dineros la vara". AHN, Nobleza, Osuna, Carp. $40, \mathrm{n}^{\mathrm{o}} 1$.

${ }^{91}$ Por albalá del rey de 3 de abril de 1380 el camarero Juan Sánchez recibió de López de Estúñiga 756 maravedíes en reales de plata para comprar 30 libras de anís y 15 de "gingibrate". AHN, Nobleza, Osuna, Carp. $40, \mathrm{n}^{\circ} 1$.

92 AHN, Códices, 1.369B, fol. 14. Citado por F. de P. Cañas Gálvez, El itinerario ..., p. 54, nota $\mathrm{n}^{\circ} 190$.

93 J. De Salazar y Acha, La Casa..., pp. 4582 y 482. Véase también R. Sánchez Saus, Las élites..., pp. 44-45.

${ }^{94}$ En 1370 ya era señor de Arrendó. El oficio de camarero mayor le había sido concedido por Enrique II el 20 de abril de 1374 y confirmado por Juan I en Madrigal de las Altas Torres el 15 de mayo de 1385. J. De Salazar y Acha, La Casa ..., p. 480 y AHN, Nobleza, Frías, Leg. 178-5. 
138095. A finales de 1383 recibía del rey un total de 40.000 maravedíes de juro de heredad $^{96}$ a los que habría que añadir su quitación por el desempeño de su oficio ${ }^{97}$.

Algo menos lucrativa al parecer fue la trayectoria de Juan Carrillo, camarero mayor de Juan I desde su etapa como infante heredero (1375). En el momento de su fallecimiento, en 1386, ostentaba el oficio de alcalde de Toledo; tenía por entonces entre sus posesiones en la ciudad imperial "unas casas en la judería de Toledo..., unas casas en la judería, en el adarve de Abenhamias..., el mesón de la herrería, en la colaçion de Santo Tome..., unas casas que son dentro de la judería..., y unas casa en el adarve que llaman de la Cera" que dejó en herencia a su viuda, doña Mayor, y sus hijos Juan, Pedro, Martín, Juana y Leonor ${ }^{98}$.

\subsubsection{LAS CÁMARAS DE LA JINETA Y LOS PAÑOS Y SUS OFICIALES}

Según apuntábamos más arriba, es durante el reinado de Juan I cuando se documenta por primera vez una subdivisión en la cámara regia como consecuencia de la creciente complejidad de su estructura y el aumento y riqueza de los ajuares de la Corona. Quedaba entonces la cámara dividida en la cámara regia propiamente dicha, otra cámara de la jineta y una cámara de los paños. Al frente de cada una de ellas se encontraban su correspondiente camarero y una lista de oficiales subalternos. El camarero de la jineta tenía como principal obligación la guardia y custodia de los arreos regios de este tipo de monta. Se documenta por vez primera en abril de 1380, cuando el camarero Diego López de Estúñiga entregó a su titular, Domingo Fernández, 250 maravedíes para la adquisición de unas "estriberas doradas" "Es probable que la compra y control de "dos frenos mulares" y una silla mular "labrada de filo de oro e un freno mular que nos mandamos conprar quando entramos en Cordova" y por los que se pagaron en octubre de 1379 y abril de 1380700 y 1.000 maravedis en reales de plata respectivamente, fueran también responsabilidad de este mismo camarero ${ }^{100}$. También adscrito a esta cámara debía de estar el sellero real, encargado de labores relacionadas con el trabajo de las sillas de monta del rey. Desempeñaba el puesto maestre Lope, que también era bordador del rey. Sabemos que en enero de 1380 recibió de Diego López de Estúñiga 1.600 maravedíes "por dos siellas e dos frenos mulares que del mandamos comprar para dar al obispo de Panplona e a Ramiro de Arellano"101.

95 J. de Salazar y Acha, La Casa..., pp. 480-481. También RAH, Salazar, M-177, fols. 74r-75v.

${ }^{96}$ Por carta de privilegio dada en la Puebla de Montalbán el 20 de noviembre de 1383. RAH, Salazar, M-58, fols. $83 \mathrm{v}-84 \mathrm{r}$.

${ }^{97}$ La cuantía de esa quitación nos es desconocida en tiempos de Juan I. En época de Juan II la quitación por el oficio de camarero mayor del rey era de 40.000 maravedíes anuales como consta en 1418 el caso de Pedro Fernández de Velasco, hijo de Juan de Velasco. AGS, QC, Leg. 1, fol. 441.

${ }^{98}$ P. León Tello, Judíos de Toledo, Vol. II, Madrid, 1979, Documento 610, p. 176.

99 Por albalá de 3 de abril de 1380. AHN, Nobleza, Osuna, Carp. 40, nº 1.

${ }^{100}$ Pagados por albalaes de 8 de octubre de 1379 y 3 de abril de 1380 . AHN, Nobleza, Osuna, Carp. $40, n^{\circ} 1$.

${ }^{101}$ Por albalá de 10 de enero de 1380. AHN, Nobleza, Osuna, Carp. 40, nº 1 . 
No volvemos a tener noticias sobre la cámara de la jineta hasta 1419, año el que su titular, Juan de Velasco fallecía dejando a su hermano Fernando el oficio ${ }^{102}$.

Algo más tardía es la primera mención a la cámara de los paños, concretamente de 1385, fecha en la que Juan I nombra con este oficio en la Casa del infante don Enrique al ya referido y eficaz camarero Diego López de Estúñiga ${ }^{103}$ con la obligación principal de guardar las telas y ropas del infante en sus correspondientes arcas ${ }^{104}$.

La variedad y la calidad de las telas compradas durante los primeros años del reinado y custodiadas en esta cámara ponen de manifiesto el lujo cotidiano que rodeaba al monarca en sus aposentos privados. Por orden de Juan I se encargaban y compraban paños de Yprés, Malinas, escarlatas y otras telas de gran calidad. Estas mismas telas eran en sí mismas piezas exquisitas con las que se obsequiaba a personalidades, embajadores y nobles de alto linaje. En 1383, por ejemplo, cuando León de Armenia llegó a la corte en Badajoz recibió de Juan I "muchos paños de oro e de seda" 105.

Pero ¿cómo eran estos paños y telas a finales del siglo XIv? Las cuentas de López de Zúñiga nos ofrecen algunos detalles sobre su color, factura y calidad. Sabemos que en enero de 1380 se abonaron 31.605 maravedíes a los mercaderes Nicolao de Casabona y Juan García por "dos pieças de paño inperiales coloradas..., quatro pieças de tapete cardenas..., dos sequenos, el uno colorado e el otro prieto..., seys pieças de baldoques brocados con oro colorados..., otras quatro pieças de baldoques colorados sin oro..., e dos pieças de valdoque con oro". También, por aquellas mismas fechas, se le libraron al deán de Orense 2.757 maravedíes por la compra en Medina del Campo de "dos capiellas de paño de ricomas, la vna cardena e la otra colorada..., e quinse pieças de sequenes, las çinco prietas e las quatro cardenas e los dos blancos e el vno cabellado e los tres colorados" destinadas a la Capilla Real ${ }^{106}$. Más ricos, si cabe, fueron los "paños de oro e de seda" adquiridos en Granada por el camarero Ruy González y para los que fue preciso pagar en junio de 1380 un total de 1.950 maravedíes además de otros 880 maravedíes más para sufragar el viaje de ida y vuelta del camarero ${ }^{107}$.

Los encargados de la confección de las ropas reales guardadas en esta cámara eran los alfayates o sastres. En la corte de Juan I se documentan, al menos, tres de estos oficiales, Gabrer y Bartolomé Martínez, al servicio del rey, y Francisco Fernández, al de la reina Juana Manuel. La presencia de Gabrer, probablemente de origen francés, nos permite suponer la convivencia e influencia mutua de las modas gala y castellana en el entorno de la realeza dando lugar a diseños únicos en los que tampoco serían extraños los elementos mudéjares y los importados de la corte nazarita de Granada.

Las cuentas de López de Estúñiga nos aportan algunos datos de interés sobre la labor de estos sastres. De Bartolomé Martínez sabemos que en abril de 1380 se le

102 J. DE SAlazar y Acha, La casa..., p. 488.

103 P. López de Ayala, Crónica del rey don Juan..., p. 777.

${ }^{104}$ En junio de 1380 dos arcas de la cámara real costaron 115 maravedíes. Abonadas por albalá del rey de 8 de junio de 1380 . AHN, Nobleza, Osuna, Carp. 40, $n^{\circ} 1$.

105 P. López de Ayala, Crónica del rey don Juan..., p. 544.

106 Pagados por albalaes del rey de 7 y 10 de enero de 1380 . AHN, Nobleza, Osuna, Carp. $40, \mathrm{n}^{\circ} 1$.

${ }^{107}$ Por albalá de 8 de junio de 1380. AHN, Nobleza, Osuna, Carp. 40, nº 1. 
entregaron 248 maravedíes por "veynte e dos terçias de çendal verde de lo angosto..."; además de 12 varas de "çintas de oro anchas que pesaron ocho onças e una ochava"; 4 "çintas de seda que puso en algunas ropas que nos le mandamos faser"; y una docena de hebillas y 50 brazas de cintas que puso en los paramentos de sarhahan que guarneció en Córdoba y Sevilla ${ }^{108}$. Gabrer, por su parte, recibía en junio de 1380 un total de 110 maravedíes para la confección de "los jubones e opas que nos le mandamos faser" ${ }^{109}$. Quizá uno de estos dos sastres fue el encargado de realizar el sombrero del rey que tenía encima una corona bordada con "tres onças de seda" y que costaron un total de 42 maravedíes, o las andas "aforradas en paño de ricomas colorado y çendal colorado" que se hicieron para la reina en abril de $1380^{110}$.

El trabajo de los alfayates se complementaba con el de los peleteros o pellejeros, oficiales cuya participación en la elaboración de las ropas regias fue ganando protagonismo durante la Baja Edad Media siendo su presencia indispensable entre los oficiales de cualquier miembro de la realeza y la alta nobleza en aquella época de creciente lujo y riqueza en la indumentaria ${ }^{111}$. Juan I contó con, al menos, un pellejero a su servicio, Salomón, a quien en diciembre de 1379 se le abonaron 250 maravedíes "por tres armiños que del mandamos conprar a Iohan Sanchez, de la nuestra camara, para poner en vna opa nuestra... e por seys armiños pequeños que nos mandamos conprar para poner en una opa nuestra, contando cada armiño por dies e siete maravedis e çinco dineros, que montan çiento e çinco maravedis" "112.

Una vez diseñada la ropa por el alfayate o sastre y ornamentada con las ricas pieles de armiños, el trabajo de los borladores o bordadores remataba el aspecto final de las ropas reales o de cualquier otro paño lujoso destinado al ornamento de la corte o la Capilla Real. Dos de estos bordadores sirvieron a Juan I durante los primeros años de su reinado. Maestre Lope, que además de, como ya vimos, de sellero del rey, era bordador de Juan I, cobró en diciembre de 1379 una suma de 5.500 maravedíes "para algunas cosas que le mandamos faser" y otros 42 maravedíes por "quatro docenas de hevillas..., e por quarenta e çinco braças de çintas..., estas hevillas e çintas mandamos poner en tres paños de seda" ${ }^{113}$. Ferrant González, el otro bordador real, percibía en abril de 1380 un total de 46 maravedíes para comprar "dos onças de seda e quatro varas de lienço de que borlaron las bandas de aljofar que nos mandamos faser en Valladolid", además de 860 maravedíes más en reales de plata para la compra de 41 cintas de seda "de que se fisieron la flocadura para el estandarte del rey de Françia. Los maestros que cosieron este estandarte y la flocadura recibieron 123 maravedíes ${ }^{114}$.

${ }^{108}$ Por albalá de 3 de abril de 1380. AHN, Nobleza, Osuna, Carp. 40, n 1.

109 En junio de 1380 dos arcas de la cámara real costaron 115 maravedíes. Abonadas por albalá del rey de 8 de junio de 1380. AHN, Nobleza, Osuna, Carp. 40, n 1.

${ }_{110}$ Por albalá de 3 de abril de 1380. AHN, Nobleza, Osuna, Carp. 40, $\mathrm{n}^{\circ} 1$.

${ }^{111}$ Sobre el papel de los peleteros en la corte de Juan II véase F. de P. CAÑas Gálvez, "La cámara...", pp. 161-165.

${ }^{112}$ Por albalá de 24 de diciembre de 1379. AHN, Nobleza, Osuna, Carp. 40, nº 1.

113 Por albalá de 24 de diciembre de 1379. AHN, Nobleza, Osuna, Carp. 40, $\mathrm{n}^{\circ} 1$.

${ }^{114}$ Por albalá de 3 de abril de 1380. AHN, Nobleza, Osuna, Carp. 40, n 1. 
Según apuntábamos unas líneas más arriba, los camareros de la cámara de los paños también debían custodiar las mantas de pared y paños franceses que colgaban de los muros de los aposentos regios. Las noticias que tenemos sobre estas piezas son escasas, pero nos permiten comprobar que se trataba de piezas lujosas elaboradas con los mejores materiales si tenemos en cuenta el precio que alcanzaron. En diciembre de 1379, por ejemplo, se documentan en la corte un total de cuatro mantas de pared que habían sido compradas en Valladolid por un valor de 3.025 maravedíes. Sus dimensiones no eran grandes, pues oscilaban entre las 16 y 17 varas de largo por las 4 ó 4,5 de ancho, oscilando su valor entre los 785 y los 720 maravedíes ${ }^{115}$.

Desconocemos si hubo a finales del siglo xIV maestros castellanos encargados de realizar tapices, lo que sí es seguro es que durante la centuria siguiente no fue extraña la presencia de maestros franceses para su elaboración en la corte de Castilla. Así ocurrió, por ejemplo, con Niculas Galcoint, que en agosto de 1453 se encontraba al servicio de Juan II como "maestro de paños françeses del dicho señor rey". Entre sus obligaciones, además de la elaboración de estas piezas, estaba la de su mantenimiento, reparación y guarnecido ${ }^{116}$.

\subsubsection{LA ARMERÍA REAL}

No es posible determinar con seguridad si en tiempos de Juan I existía ya una cámara de las armas del rey. Las primeras menciones al respecto datan del reinado de Juan II, concretamente de 1440, cuando el oficio de camarero de las armas del príncipe recayó en Enrique Juan de Padilla ${ }^{117}$.

Desde, al menos, finales del siglo XIII existió una estrecha relación entre los oficios de camarero y armero real, siendo, incluso, en alguna ocasión ostentados ambos cargos por un mismo individuo ${ }^{118}$. En época de Juan I se documentan dos armeros al servicio del rey y trabajando, al menos uno de ellos, bajo las órdenes del camarero Diego López de Estúñiga. Este es el caso de Alfonso Ruiz, a quien en abril de 1380 se le entregaron 182 varas de lienzo para forrar unas mantas de paño de "Yprés que andan sobre las nuestras armas... e por veynte braças de çintas" "11.

La principal obligación de estos armeros era la custodia y cuidado de las armas y arneses del monarca. En otras ocasiones parece que también eran los encargados de proveer de armas los castillos del rey. En abril de 1385, por ejemplo, el armero real Alfonso Martínez recibió de la ciudad de Sevilla 600 maravedíes por 30 "escudos paveses" que se le habían comprado para la guarda y defensa del castillo de Aroche ${ }^{120}$.

${ }^{115}$ Por albalá de 1 de diciembre de 1379. AHN, Nobleza, Osuna, Carp. 40, nº 1.

116 AGS, CySR, Leg. 42, fol. 1j.

117 En los años finales del reinado Pedro de Perea y Rodrigo fueron camareros de las armas del rey F. de P. CAÑas GÁlvez, "La cámara....", pp. 170-171.

118 Juan Mathé de Luna fue camarero y armero mayor de Sancho IV entre 1286 y 1294. J. De SALAZAR y Acha, La Casa..., p. 477.

119 Por albalá de 3 de abril de 1380. AHN, Nobleza, Osuna, Carp. 40, nº 1.

120 F. Collantes de Terán, Inventario de los papeles del mayor domazgo del siglo XIV, Sevilla, 1968, p. 26. 
Las noticias que conservamos sobre las armas y arneses pertenecientes al rey son también escasas para los años del reinado de Juan I, aunque estas piezas deslumbraban en muchas ocasiones por su riqueza. Sabemos que el camarero López de Estúñiga pagó en octubre de 1379 por dos cajas de bacinetes 700 maravedíes. Por aquellas mismas fechas se abonaban otros 250 maravedíes "por dos canales para estos baçinetes". Los bacinetes se adornaron con estofas (tejidos de colores) que costaron 70 maravedíes, mientras que los arneses lo fueron con 4 onzas de seda por un valor de 154 maravedíes. Por su parte, dos arneses de piernas costaron 400 maravedíes y dos pares de guantes 200. Las hebillas de los arneses estaban realizadas con plata ${ }^{121}$.

Los estoques reales eran elaborados con materiales de gran calidad y sus acabados eran esmerados. En octubre de ese mismo año "dos fierros de estoques" costaron 200 maravedíes, mientras que por dorar sus manzanas, "arrases", cabos y hebillas se pagaron 226 maravedíes. Las empuñaduras y conteras estaban rematadas con hilo de plata $^{122}$. Estos debían de ser los estoques que a manos de un oficial regio encabezaban desenvainados las comitivas regias que precedían al rey. Desconocemos el nombre de las personas que desempeñaron el oficio de estoque del rey en tiempos de Juan I aunque es probable que todavía fuera ostentado por el merino mayor, como sucedía en tiempos de Alfonso XI ${ }^{123}$.

\subsection{LA MESA DEL REY}

Apenas disponemos de noticias que ilustren sobre el ceremonial que se seguía en la corte de Castilla de los primeros Trastámaras a la hora de servir la mesa al rey. Su coordinación, tanto en los grandes banquetes como en las comidas regias más privadas, era responsabilidad del mayordomo mayor y bajo su coordinación trabajaban un importante número de oficiales. Cabe suponer que en tiempos de Juan I este ceremonial debía de haber alcanzado un grado alto de solemnidad y complejidad, aunque la inexistencia de determinados oficiales como los maestresalas, documentados en la corte castellana sólo a principios del siglo $\mathrm{XV}^{124}$, nos induce a pensar que el ritual estaba todavía a finales del XIV en un proceso de gestación, evolución y desarrollo que culminaría gradualmente durante los reinados de Juan II, Enrique IV y los Reyes Católicos ${ }^{125}$.

A falta de documentación explícita, algunas imágenes nos ayudan a perfilar con una mayor precisión cómo debía de ser una comida cotidiana en la corte castellana a mediados del siglo XIv. En una conocida ilustración del Libro de Montería de Alfonso XI podemos ver al monarca sentado solo en la mesa. Detrás de él se encuentra

${ }^{121}$ Por albalá de 8 de octubre de 1379. AHN, Nobleza, Osuna, Carp. 40, $n^{\circ} 1$.

${ }^{122}$ Por albalá de 8 de octubre de 1379. AHN, Nobleza, Osuna, Carp. 40, $\mathrm{n}^{\circ} 1$.

${ }^{123}$ No fue hasta las primeras décadas del siglo XV cuando el oficio quedó vinculado definitivamente a la familia Álvarez de Toledo. J. De SalazAr y Acha, La Casa..., pp. 306-307.

${ }^{124}$ El primer maestresala al servicio del rey data de 1407 en la persona de Micer Ventolín. J. DE Salazar y Acha, La Casa..., p. 511.

${ }^{125}$ Véase, en relación a las respectivas esposas de Juan II y Enrique IV, F. de P. CAÑas Gálvez, "Las Casas...”, pp. 53-60. Con respecto a los Reyes Católicos Ma del C. GonzÁlez Marrero, La Casa de Isabel la Católica. Espacios domésticos y vida cotidiana, Ávila, 2004, pp. 82-86. 
quien es, seguramente, su mayordomo mayor supervisando los alimentos y bebidas que acercan dos oficiales; uno de ellos es el trinchante que se dispone a cortar la carne al monarca ${ }^{126}$; el otro, es el copero, que también con la rodilla en el suelo, ofrece al rey una copa. Detrás del rey, hay varias personas, entre ellas, el oficial de la escudilla ${ }^{127}$, le siguen el repostero mayor, el copero mayor 128 , y, seguramente, el físico, haciendo la salva para descartar que 10s alimentos estuvieran en mal estado o envenenados ${ }^{129}$. La mesa era servida en piezas cuya cuantía y lujo dependía, seguramente, de la ocasión. En 1383, por ejemplo, con motivo de la visita de León de Armenia a la corte de Castilla en Badajoz, Juan I le obsequió, entre otros objetos de gran valor, con "vajillas de plata"130.

La preparación de los alimentos conllevaba un proceso de elaboración no exento de cierta complejidad. El responsable máximo de esta función era el cocinero mayor, un oficial del que no tenemos noticias durante el reinado de Juan I aunque debieron de ser excelentes. Sabemos que durante las mencionadas bodas de Juan I y Beatriz de Portugal, el infante don Carlos de Navarra ofreció un banquete al rey de Castilla, al mencionado León de Armenia, al cardenal Pedro de Luna y a varios arzobispos, obispos y nobles castellanos y portugueses en la que la participación combinada de los cocineros castellanos y navarros fue muy destacada recibiendo por ello los dichos cocineros 30 florines de merced del infante ${ }^{131}$.

Por su parte, la elección de los productos y las materias primas con las que se cocinaban los platos, así como los vinos, que se servían al monarca era competencia del despensero mayor y de los despenseros menores ayudados, al menos así lo era un siglo más tarde, en tiempos de los Reyes Católicos, por un veedor que examinaba los precios de los alimentos y asesoraba al despensero sobre la conveniencia de elegir tal o cual producto ${ }^{132}$. La compra de fruta era competencia exclusiva del frutero ${ }^{133}$.

126 En 1385 Juan I nombró a Juan Martínez de Medrano del infante don Enrique aunque no sabemos si llegó a desempeñar el oficio pues murió en la batalla de Aljubarrota aquel mismo año. Álvaro de Villaizán lo fue ese mismo año del infante don Fernando. P. López DE AyALA, Crónica del rey don Juan..., pp. 603 y 777.

127 En 1385 Juan Duque fue nombrado oficial de la escudilla del infante don Enrique. Un año antes era mencionado por LóPEz DE AyAla como "caballero de Castilla”. Trinchante del infante don Fernando fue el "hijo de Lope Fernández de Vega", su repostero mayor.

P. LóPEz de Ayala, Crónica del rey don Juan..., pp. 570 y 777.

${ }^{128}$ En tiempos de Juan I fueron coperos mayores Alvar García de Albornoz (1380- $\left.\uparrow 1385\right)$ y su sobrino Juan de Albornoz (1385-1389). Este último había sido nombrado copero mayor del infante don Enrique en 1385. Reposteros mayores fueron: García Fernández Sarmiento (1385), Diego Gómez Manrique (1378-1379-†1385) y Diego Gómez Sarmiento (1380-†1386). J. De Salazar y AcHA, La Casa..., pp. 491, 492 y 499.

129 J. de Salazar y Acha, La Casa..., p. 275.

${ }^{130}$ P. López de Ayala, Crónica del rey don Juan..., p. 544.

131 AGN, Comptos, Registro 172, fol. 39v.

132 G. Fernández De Oviedo, Libro de la cámara del príncipe don Juan Edición de Santiago Fabregat Barrios, Valencia, 2006, pp. 126-127.

133 En abril de 1380 Juan Sánchez de Medina era frutero de Juan I. Su ración mensual ascendía a 180 maravedíes. Librada por albalá de 3 de abril de 1380. Probablemente se trate del mismo Juan 
El control económico general de la despensa estaba supeditado a un contador de la misma $^{134}$.

Debido sus importantes responsabilidades, los despenseros eran oficiales de la máxima confianza y lealtad al monarca, aunque no parece que fueran de noble linaje como parece que ocurrió con Ferrant Gascón, despensero mayor de Juan I desde su etapa como infante heredero, en 1374, hasta, al menos, 1386, y de orígenes seguramente modestos.

Algunas noticias nos permiten asegurar que entre las obligaciones de los despenseros estuvieron también las de carácter burocrático-administrativo como ordenar el pago de raciones y quitaciones a algunos oficiales de la corte. En diciembre de 1379, por ejemplo, Juan I entrego a su despensero mayor Juan Núñez 35.000 maravedíes para "la despensa de nuestra casa" y en 1380 otros 8.000 más para el pago de raciones a los oficiales de la Casa del rey135. En otras ocasiones, sus obligaciones fueron algo más difusas y ajustadas a necesidades puntuales del momento. En julio de 1379, el rey había ordenado a las autoridades de la ciudad de Burgos que llevaran al monasterio de las Huelgas y entregaran a su despensero mayor Juan Gómez "las mas calderas e tajaderas e escudiellas que pudieres aver... para estas onrras que yo agora aqui tengo" en clara alusión a su próxima coronación en el cenobio burgalés

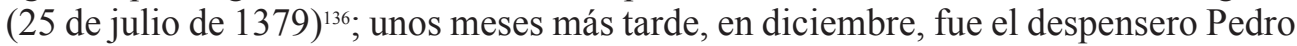
Martínez quien recibió por orden del rey 13.000 maravedíes aunque no se especifica el destino del dinero ${ }^{137}$.

Por último, señalar la existencia de un despensero de los caballeros del rey y del infante en la persona de Juan de San Pedro en 1385. Suponemos que su cometido debía de ser idéntico al de los despenseros reales ${ }^{138}$.

Sánchez, frutero de Enrique III, fallecido en 1046. AHN, Nobleza, Osuna, Carp. 40, nº 1; y A. RucQuoI, Valladolid en la Edad Media, Vol. II, Valladolid, 1997, p. 89.

${ }^{134}$ Sabemos que Ferrand Pérez de Villafranca fue nombrado con este oficio por Juan I en la Casa de su hijo el infante don Enrique, oficio que, sin embargo, no se designó, en un primer momento, en la Casa del infante, aunque sí sabemos que tenía un despensero años más tarde, en 1389, Alfonso García. P. López de Ayala, Crónica del rey don Juan..., p. 778 y G. DE Quintana, A la muy antigua y connada villa de Madrid, II, Madrid, 1629, p. 315.

${ }^{135}$ Por albalá de 8 de enero de 1380. Juan Núñez todavía ejercía el oficio en 1389, fecha en la que afirmaba haber sido en 1386 arrendador de las alcabalas del obispado y reino de Murcia. AHN, Nobleza, Osuna, Carp. 40, nº 1; y J. M. Díez Martínez, A. Bejarano y A. L. Molina Molina, Documentos..., Documentos 231 y 271 , pp. 449-451 y 500-502, respectivamente.

${ }^{136}$ Por albalá de 13 de julio de 1379. AM, Burgos, Libros de Actas, 1388, fol. 77v. L. SuÁrez FerNÁNDEZ, Historia del reinado..., II, Documento 22, pp. 35-36.

${ }^{137}$ Librados por albalá de Juan I de 31 de diciembre de 1379. AHN, Nobleza, Osuna, Carp. 40, nº 1.

${ }^{138}$ P. López de Ayala, Crónica del rey don Juan..., p. 778. 


\subsection{LA ATENCIÓN SANITARIA: FÍSICOS Y PARTERAS EN LA CORTE DE CASTILLA}

Juan I estuvo atendido a lo largo de su reinado por un equipo de médicos, la mayor parte de ellos judíos ${ }^{139}$, de calidad excepcional si tenemos en cuenta sus trayectorias profesionales y la frecuencia con la que fueron requeridos por parte de la realeza peninsular. En septiembre de 1383, por ejemplo, estando enfermo en Segovia el infante don Carlos de Navarra fue tratado por varios físicos de Juan I, de la infanta Leonor y del cardenal de Aragón a los que don Carlos gratificó con 200 florines ${ }^{140}$. Otro físico de Juan I, del que no se menciona su nombre, fue el encargado de atender a dos oficiales de don Carlos, Maite de Villiers y Jean Le Roux, recibiendo por ello 10 florines por el mismo concepto ${ }^{141}$.

Debió de quedar don Carlos tan satisfecho entonces del trato recibido por los físicos de Juan I que años más tarde no dudó en hacerse con los servicios de algunos de ellos para su corte en Navarra. Entre los médicos que contrató estaba Mayer Algoadix, físico de Juan I y Enrique III. El infante Carlos de Navarra, que debió conocerle durante el Sitio de Lisboa en la primavera de 1384, le llamó a su servicio en 1394, cuando ya era físico de Enrique III y don Carlos se había convertido en rey. El monarca navarro le pagó "por çiertos servicios que auia fecho" 105 florines, que equivalían a 136 libras y 10 sueldos $^{142}$. También durante aquella estancia en Castilla, el infante conoció a otro físico judío de Juan I, el judío Jacob. De vuelta a su reino, don Carlos decidió llevárselo a su corte y en abril de 1387 trató de una "enfermedad" en la mano a uno de los menestrales reales. Por sus servicios, Carlos III le pagó sus expensas durante su estancia en Navarra y el regreso a la corte de Castilla ${ }^{143}$.

De Juan Guillén, en cambio, no tenemos noticias sobre posibles servicios a otros monarcas peninsulares de la época, pero fue, además de físico de Juan I y bachiller, el médico encargado de examinar a los aspirantes al oficio de físico, un aspecto, este último, que evidencia su excelencia en el oficio. Como tal, en marzo de 1385, fue el encargado de probar las aptitudes de Yuçaf Abenalazar como futuro médico. Los resultados fueron positivos y, en palabras del propio Guillén, Abenalazar resultó ser

139 Eran los únicos oficiales de este origen que podían trabajar en la corte real, según se había dispuesto por Juan I en las Cortes de Briviesca, y únicamente "en tiempo de necesidad". Judíos fueron también dos físicos al servicio del arzobispo toledano Pedro Tenorio. Del primero de ellos, Ressac, sabemos que fue el encargado de tratar al infante don Carlos de Navarra durante la dolencia que le mantuvo en cama en Valladolid en el otoño de 1385. Recibió por ello 10.000 maravedíes. El otro físico judío del arzobispo, rabí Haym, era descrito en 1388 como "omne de buen linaje e cuerdo e bueno e bien letrado”. Cortes..., II, p. 422; AGN, Comptos, Registro 172, fol. 105v; y P. León Tello, Judios de Toledo, Vol. II, Madrid, 1979, Documento 617, p. 177, respectivamente.

${ }_{140}$ AGN, Comptos, Registro 172, fol. 41v.

${ }^{141}$ AGN, Comptos, Registro 172, fol. 41r.

142 F. Serrano Larráyoz, Medicina y enfermedad en la corte de Carlos III el Noble de Navarra (1387-1425), Pamplona, 2004, p. 55.

${ }_{143}$ AGN, Comptos. Registros, no 193, fol. 42v. F. Serrano Larráyoz, Medicina y enfermedad ..., p. 55. 
“... çierto para la dicha çiençia de fisica... tanbien en el arte de la pratica commo de la teoria..." ${ }_{144}$.

Los datos que poseemos sobre los otros dos físicos al servicio de Juan I son aún menores. De Mosé Aben-Abraham Aben Zarzal sabemos que era hijo de un físico de Pedro I ${ }^{145}$ mientras que de maestre Berenguel tan sólo consta que el rey le nombró abad de Covarrubias y su infantado, seguramente en premio a servicios prestados al rey o la Familia Real ${ }^{146}$.

Tampoco son abundantes las noticias sobre los físicos al servicio de las esposas de Juan I. De la primera de ellas, Leonor de Aragón, no conservamos dato alguno, mientras que de Beatriz de Portugal tan sólo hemos podido saber que estuvo atendida por, al menos, dos físicos, ambos en el año 1394: el bachiller en medicina Gil Domínguez, rector parroquial de la iglesia de Santiago, en la diócesis de Braga, familiar y continuo comensal; y Gil Fernández, también bachiller en medicina, capellán de honor de la reina y clérigo de Évora' ${ }^{147}$. Más tardías son las noticias sobre el cirujano que la atendía en septiembre de 1419, maestre Fernando ${ }^{148}$.

No tenemos ninguna información sobre cirujanos y boticarios en la corte de Castilla durante aquellos años y tampoco son abundantes las relacionadas con las parteras. La presencia de la partera valenciana Nabona Nada en octubre de 1379 en la corte de Juan I está, sin duda, relacionada con el nacimiento del infante don Enrique que tuvo lugar el 4 de octubre de ese mismo año en Burgos. Nabona era, al igual que la mayor parte de parteras al servicio de la Familia Real, de origen musulmán. El prestigio profesional de estas mujeres está bien contrastado a lo largo del siglo XV en Castilla y Navarra ${ }^{149}$. No es de extrañar, por tanto, que Juan I hiciera venir desde tan lejos a esta mujer para garantizar el buen nacimiento de su primer hijo y la seguridad de la madre. El éxito del trabajo realizado entonces se tradujo pronto en la concesión de importantes mercedes. En octubre de ese mismo año, pocos días después del nacimiento del infante, Juan I entregó a Nabona 5.000 maravedíes en cuenta de los 10.000 que se le debían pagar, además de otros 5.000 maravedíes más que equivalían a 1.666 reales $^{150}$. Las gratificaciones también se extendieron a sus familiares y así en diciembre de 1379 fue el hijo de Nabona, Miguel Cardona, el beneficiario de 6.000 maravedíes ${ }^{151}$.

${ }^{144}$ La carta de aprobación de Guillén está fechada en Valladolid el domingo 12 de marzo de 1385. La confirmación del rey, en Madrigal de las Altas Torres el 17 de abril de ese mismo año. J. M. DíEz Martínez, A. Bejarano y A. L. Molina Molina, Documentos..., Documento 173, pp. 340-342.

${ }_{145}$ P. LeÓn Tello, Judios de Toledo, Vol. I, Madrid, 1975, p. 168.

${ }^{146}$ L. Serrano, O.S.B., Los conversos D. Pablo de Santa María y DAlfonso de Cartagena, obispos de Burgos, gobernantes, diplomáticos y escritores, Madrid, 1942, p. 18.

${ }^{147}$ C. Olivera Serrano, Beatriz de Portugal..., pp. 222 y siguientes.

148 R. Vicente Baz, Los libros de actas capitulares de la catedral de Salamanca (1298-1489), Salamanca, 2008, Documento 731, p. 303.

149 F. de P. Cañas Gálvez, "Las Casas...", pp. 82-83.

${ }^{150}$ Por albalaes de 20 y 26 de octubre de 1379, respectivamente. AHN, Nobleza, Osuna, Carp. 40, $\mathrm{n}^{\mathrm{o}} 1$.

${ }^{151}$ Pagados por albalaes de 24 de diciembre de 1379 y 8 de enero de 1380 . AHN, Nobleza, Osuna, Carp. $40, \mathrm{n}^{\circ} 1$. 
Tras el trabajo realizado por las parteras, cobraba relevancia el de las amas y en especial el de las amas de leche. Su labor era esencial para que el bebé tuviera una buena nutrición que optimizara sus posibilidades de supervivencia. En este sentido, es bien conocido el interés que puso Enrique III en la elección de las amas que deberían atender a su hijo, el infante Juan ${ }^{152}$. Las amas, aunque no se especifica que lo fueran de leche, que trataron al infante Enrique tras su nacimiento en 1379 fueron Beatriz García y Beatriz Martínez. Ambas fueron magníficamente compensadas por los servicios prestados. Beatriz García recibió de merced vitalicia las tercias de Torrelobatón y su Tierra que todavía disfrutaba en $1401^{153}$, mientras que Beatriz Martínez lo sería en noviembre de 1379 con una merced de 900 maravedíes ${ }^{154}$.

\subsection{LOS DIVERTIMENTOS DEL REY: JUGLARES Y MINISTRILES. JUEGOS DE NAVIDAD EN LA CORTE}

El reinado de Juan I supuso desde el punto de vista musical una época de interesantes aportaciones en el desarrollo de este arte en tierras castellanas. Los testimonios documentales son también claros a la hora de poner de manifiesto el interés de Juan I por contar con los mejores músicos del momento y, sobre todo, la decidida protección que Juan I les dispensó siempre. Todo ello respondía, además de a las aficiones puramente melómanas de la realeza, a un contexto político y cultural determinado y extensible por entonces a toda Europa occidental en el que las artes en general y la música en particular comenzaban a jugar un papel de primer orden en la creación y consolidación de una imagen de la autoridad regia magnífica y solemne en estrecha relación con su creciente capacidad de gobierno y autoridad. Una buena prueba de este patronato es la identificación con divisas o libreas, o ambas cosas, de los músicos reales sobre el resto de oficiales, una práctica consolidada ya por entonces en una buena parte de las cortes europeas ${ }^{15}$. En el caso de Juan I sabemos que en abril de 1380 las divisas de sus juglares fueron adornadas con plata por Andrés, platero de Leonor de Aragón. La suma gastada para este cometido fue de 680 maravedíes $^{156}$.

Las gratificaciones económicas a sus músicos, denominados en la documentación coetánea como juglares y ministriles indistintamente ${ }^{157}$, como una forma más de la magnificencia regia debieron de ser frecuentes durante años. En febrero de 1380 Juan I ordenó el pago de 1.300 maravedíes para comprar una mula a sus ju-

${ }^{152}$ F. de P. CAÑas Gálvez, "La cámara...”, pp. 128-129.

${ }_{153}$ AGS, MyP, Leg. 1, fol. 399.

${ }_{154}$ Por albalá de 16 de noviembre de 1379. AHN, Nobleza, Osuna, Carp. 40, nº 1.

${ }^{155}$ Para el caso de Borgoña, Aragón y Castilla véase F. de P. CAÑAs Gálvez, "La música en la corte de Enrique IV de Castilla (1454-1474). Una aproximación institucional y prosopográfica”, Revista de Musicología, XXIX, 1 (2006), pp. 217-313, en especial la p. 255. Para Navarra véase Ma NARBONA CÁrceles, "La consideración del juglar en la corte de Caros II y Carlos III de Navarra, a través del estudio de su atuendo", Mito y realidad en la historia de Navarra, Vol. 1, Pamplona, 1998, pp. 429-442.

${ }^{156}$ Por albalá de 3 de abril de 1380. AHN, Nobleza, Osuna, Carp. 40, n 1.

${ }^{157}$ Fue durante la primera mitad del siglo XV cuando el término ministril se impuso definitivamente en Castilla al de juglar para denominar a los músicos al servicio de la realeza. F. de P. CAÑAs GÁlvez, "La música en la corte de Juan II de Castilla (1406-1454). Nuevas fuentes para su estudio", Revista de Musicología, XXIII, 2 (2000), pp. 375-376. 
glares y entregaba otros 1.000 maravedíes para otros juglares suyos que "casaron en Burgos" ${ }^{158}$ y dos meses más tarde, en abril, y quizá deslumbrado por la interpretación, mandaba librar "a un moçuelo pequeño que disen Alfonso por quanto canto el dia de Pascua sobrel sepulcro de Ihesuchristo" 201 maravedíes en doblas moriscas ${ }^{159}$.

En sus gustos musicales debió de influir, seguramente de manera determinante, el papel desempeñado por su cuñado Juan I de Aragón, uno de los mecenas musicales más destacados de la Baja Edad Media. La corte aragonesa se convirtió en aquellos años en centro de reunión de los músicos más notables del momento. El monarca, siendo aún infante, contó con una capilla musical esplendorosa en la que brillaron con una especial fuerza los cantores y ministriles venidos de tierras del Norte de Europa y los repertorios vanguardistas del Ars Subtilior ${ }^{160}$.

El intercambio entonces de músicos entre las cortes de Castilla, Aragón fue, por razones de parentesco, muy fluido. La década que transcurrió entre 1375 y 1382, el trasiego de ministriles de una corte a otra fue constante ${ }^{161} \mathrm{y}$ los ejemplos de ellos son numerosos. En agosto de 1373 sabemos que cuatro ministriles del infante Juan de Castilla, Johan Bocs, Johan de Gales, Joan Bruniqui y Johan Sanç se encontraban temporalmente al servicio de la reina Leonor de Sicilia ${ }^{162}$. La afluencia a Castilla de ministriles procedentes de Aragón fue también notable. En julio de 1379, por ejemplo, el infante Juan de Aragón envió a Castilla a sus ministriles Martí, Oloqui y Midach, músico, este último, a quien el infante denominaba "Rey dels ministrers d'Alemanya e de França e d'aquesta tierra (Aragón) y para el que pedía igual reconocimiento en Castilla" para solemnizar la coronación del Trastámara en el monasterio de las Huelgas ${ }^{163}$. Además de los ya conocidos ministriles Jaquet Portaubert, Johan de Alemania y Johani Auber ${ }^{164}$, contamos con el caso del músico, según se le denomina en la documentación, Cristófol de Eslavonia, ministril de Juan I de Castilla en 1380. Con anterioridad había servido en la corte de Leonor de Sicilia (1368-1369) y en la de su marido, Pedro IV de Aragón (1378), junto a su hermano Angelino de Eslavonia $^{165}$.

Tras el fallecimiento de la esposa de Juan I de Castilla, Leonor de Aragón, en 1382, el flujo musical entre ambas cortes disminuyó de manera evidente aunque no por ello desapareció. Se registran durante aquellos años las visitas a Castilla de algunos notables ministriles enviados por Pedro IV a su antiguo yerno. En febrero

${ }^{158}$ Librados por albalaes de 11 y 20 de febrero de 1380. AHN, Nobleza, Osuna, Carp. 40, no 1.

159 Por albalá de 3 de abril de 1380. AHN, Nobleza, Osuna, Carp. 40, nº 1.

${ }^{160}$ Una visión de conjunto del ambiente musical de la corte de Aragón en aquel periodo en $\mathrm{M}^{\mathrm{a}} \mathrm{C}$. Gómez Muntané, La música en la Casa Real catalano-aragonesa, Vol. I. Historia y documentos, Barcelona, 1979, pp. 1-115.

${ }^{161}$ Más detalles en F. de P. CAÑAs GÁlvez, Música, poder y monarquía en la Castilla Trastámara (1366-1474). Nuevas perspectivas de análisis", Revista de Musicología, XXXII, 1 (2009), pp. 359-378.

${ }^{162} \mathrm{M}^{\mathrm{a}}$ C. Gómez Muntané, La música en la Casa Real..., p. 70.

${ }^{163}$ M a C. Gómez Muntané, La música en la Casa Real..., doc. no 51, p. 144. Citado por F. de P. CAÑAS GÁlvez, "Música, poder y Monarquía en la Castilla Trastámara (1369-1474). Nuevas perspectivas de análisis", Revista de Musicología, XXXII, nº 1 (2009), p. 370.

${ }^{164}$ Véase F. de P. Cañas Gálvez, "Música...", pp. 364 y 365.

165 A. Descalzo, "Músicos en la corte de Pedro IV el Ceremonioso (1336-1387)", Revista de Musicología, XIII, 1 (1990), pp. 95 y 112. 
de 1385 sabemos que le recomendó al mencionado ministril de cuerda Jaquet Portaubert ${ }^{166}$ y unos años más tarde, en 1388, Juan I de Aragón escribía a Pero Boyl, consejero del rey de Castilla, recomendándole el ministril de chirimía Colinet y a sus compañeros ${ }^{167}$.

Las noticias de intercambios de músicos con Navarra son, con respecto a Aragón, algo menores pero parecen evidenciar también un importante flujo entre ambas cortes. Consta que en febrero de 1382, estando el infante don Carlos de Navarra en Castilla, ordenó pagar a los ministriles de Juan I un total de 20 florines de Aragón y 10 florines a los del marqués de Villena ${ }^{168}$. También castellanos y, en menor cuantía, navarros fueron los ministriles, trompetas y heraldos que solemnizaron la boda de Juan I y Beatriz de Portugal en Badajoz en 1383, recibiendo por ello del infante don Carlos 150 florines en concepto de merced ${ }^{169}$.

Sabemos también que en abril de 1387 dos ministriles de boca de Juan I, Mongicot y "Filz de bon padre" 170 , se encontraban en la corte de Carlos III. Su nivel profesional debía de ser muy alto y dejaron una magnífica impresión en el ánimo del monarca navarro, muy habituado desde joven a contar con músicos excelentes en su entorno ${ }^{171}$, quien les obsequió con una merced de 20 florines a Mongicot y con 15 a "Filz de bon padre". Por cierto, durante aquella estancia en Navarra, un trompeta del camarero Diego López de Estúñiga, de quien no se dice su nombre, fue también gratificado por el rey con 10 florines $^{172}$. La función de los trompetas en la corte estaba más en relación con funciones heráldicas que puramente musicales. Para estas labores heráldicas y representativas Juan I contó con un trompeta, el mencionado Johan

166 A. Descalzo, "Músicos en la corte...", p. 101.

${ }_{167}$ M a C. Gómez Muntané, La música en la Casa Real..., Documento 100, p 159.

168 AGN, Comptos, Registro 172, fols. 16v y 13r.

169 AGN, Comptos, Registro 172, fol. 39v.

${ }^{170}$ La presencia de este tipo de ministriles o juglares de boca se documenta a lo largo del siglo XIV en Castilla. En 1353, Sancho Ribares, por ejemplo, era juglar de boca de Pedro I. En 1356 era caballero salvaje del arzobispo de Zaragoza Lope Fernández de Luna, en 1358 se encontraba en la corte de Pedro IV de Aragón y en 1366 en la de Carlos II de Navarra. F. de P. Cañas Gálvez, "Música...”, p. 364.

${ }^{171}$ Sobre este aspecto véase Ma Narbona CÁrCeles, "La actividad musical en la corte de Carlos III el Noble de Navarra, 1387-1425: ¿mecenazgo o estrategia política?, Príncipe de Viana, LXVII, n 238 (2006), pp. 313-334.

172 Por orden de Carlos III a los oidores de Comptos dada en Estella el 9 de abril de 1387. AGN, Comptos, Caja 54, no 30, IX. J. R. CAstro, Catálogo del Archivo General de Navarra. Sección de Comptos. Documentos. Tomo XVI. Años 1386-1387, Pamplona, 1956, Documento 828, pp. 342-343. 
de Alemania, que también era ministril ${ }^{173}$, un número indeterminado de ballesteros de maza $^{174} \mathrm{y}$ un pregonero encargado de proclamar paces y acuerdos ${ }^{175}$.

Otro de los divertimentos reales, junto a la música, eran los enanos y los "locos", documentados, estos últimos, en Castilla a lo largo de los siglos XIV ${ }^{176} \mathrm{y} \mathrm{XV}^{177}, \mathrm{y}$, sobre todo, los juegos de dados practicados en la Nochebuena. Esta costumbre navideña, constatada plenamente en tiempos de Enrique IV, tenía, sin embargo, orígenes más antiguos y, al menos, desde finales del siglo XIV se verifica en la corte de Castilla, aunque es muy probable que gozara del aprecio del entorno áulico desde tiempos más remotos ${ }^{178}$. Las cantidades que se manejaban durante estas partidas eran considerablemente altas. Gracias a las cuentas del camarero Diego López de Estúñiga sabemos que éste entregó a Juan I en la Nochebuena de 1379 en Medina del Campo "quarenta francos de oro a treynta e un maravedi e veynte doblas de oro moriscas, a treynta e quatro maravedis, que montan mill e nueveçientos e veynte maravedis" 179 . Igualmente elevada fue la suma gastada y perdida en la Navidad de 1462 por Enrique IV jugando con don Beltrán de la Cueva "e otros caualleros que jugaron conmigo aquella noche", un total de 420 doblas y 100 enriques $^{180}$.

\subsection{LA CAPILLA REAL}

Las necesidades espirituales del rey y los miembros de la Familia Real eran competencia de sus respectivos capellanes mayores. La organización, funcionamiento y desarrollo institucional y político de esta institución experimentaron a lo largo del siglo XIV, y muy especialmente durante su segunda mitad, coincidiendo con la llegada al trono de Castilla de los Trastámara, un notable desarrollo cuantitativo,

173 Véase F. de P. Cañas Gálvez, "Música...”, pp. 364 y 365.

174 Estos ballesteros, en ocasiones desempeñaban funciones de mensajeros reales. En abril de 1380 sabemos que el ballestero de maza Alfonso Fernández de Toledo recibió 200 maravedíes en reales de plata "para quando lo enbiamos desde Cordova a la reina, nuestra madre" y por esas mismas fechas Juan González, otro ballestero, percibía 600 maravedíes en reales de plata "para quando lo enbiamos desde Cordova al duc de Angeos". Librados por albalaes de 3 de abril de 1380. AHN, Nobleza, Osuna, Carp. $40, \mathrm{n}^{\circ} 1$.

${ }^{175}$ Con este oficio servía al infante don Juan Pedro García en 1375. Fue el encargado de pregonar las paces acordadas entre castellanos y aragoneses aquel año. Así aparece en carta del infante fechada en Almazán el 12 de abril de 1375. L. Pascual Martínez, Documentos..., Documento CLXXVII, pp. 283-284.

176 Sabemos que el 4 de febrero de 1382 desde Castilla el infante don Carlos de Navarra ordenó el pago de un florín a "un loco que fue del rey de Castilla". AGN, Comptos, Registro 172, fol. 16v.

177 F. de P. Cañas Gálvez, "Las Casas...”, pp. 98-99.

${ }^{178}$ Sobre todo en la corte de Alfonso X. El propio rey escribió un tratado sobre los juegos de dados titulado Libro de los juegos: acedr ex, dados e tablas: or denamiento de las tafuerias, Fundación José Antonio de Castro, Madrid, 2007.

179 Por albalá de 8 de enero de 1380. AHN, Nobleza, Osuna, Carp. 40, nº 1 .

${ }^{180}$ Citado por M. A. LAdero Quesada, "1462: Un año en la vida de Enrique IV, rey de Castilla”, En la España Medieval, nº 14 (1991), p. 247. 
paralelo, sin duda, al que por entonces también se verificaba en el plano burocráticoadministrativo de la Corona ${ }^{181}$.

Con respecto a la procedencia de los capellanes mayores a finales del siglo XIV no hubo novedades en relación a etapas anteriores, es decir, todos eran miembros del alto clero castellano. Tanto Rodrigo de Moscoso como su sucesor en el oficio en época de Juan I, Juan García Manrique, habían sido arzobispos de Santiago; además, ambos, contaban con la preparación suficiente como para haber ostentado los oficios de notarios mayores del Reino de León; en el caso de García Manrique sabemos que fue además de doctor, oidor de la Audiencia Real y canciller mayor de Enrique II, Juan I, Enrique III (1379-1391) y la reina Juana Manuel (1380), además de notario mayor de los privilegios rodados de Enrique II (1367) ${ }^{182}$.

En el caso de las reinas consortes, la excelencia de sus capellanes mayores queda también constatada, aunque quizá sea posible advertir un nivel algo inferior en cuanto a la procedencia eclesiástica de sus miembros, pero no así en el desarrollo de sus trayectorias posteriores. El capellán mayor de Juana Manuel, Gutierre Gómez de Toledo, había llegado a ser obispo de Palencia (1357) y más tarde de Oviedo (1377-1389), sedes, ambas, de menor importancia, aunque en el cenit de su andadura curial llegó a ser nombrado cardenal de San Juan y San Pablo por Urbano VI (1381) y cardenal por Clemente VII. Más limitadas, en cambio, y por razones evidentes si tenemos en cuenta el retiro en el que vivió esta soberana tras el fallecimiento de su marido, fueron las trayectorias profesionales seguidas por algunos de los capellanes mayores de Beatriz de Portugal. De Alfonso Martínez, sabemos que fue deán en Braga y bachiller en decretos y sagrada escritura (1394), mientras que Pedro Rodríguez de Fonseca llegó a ostentar el título de bachiller en leyes alcanzando en 1394 el capelo cardenalicio ${ }^{183}$.

Se trataba en todos los casos, y ahí está la principal novedad, de eclesiásticos bien formados jurídicamente y especialmente hábiles en el manejo de los negocios diplomáticos de la Corona, algo que, sin duda, repercutía en una imagen exterior muy positiva de la monarquía castellana ${ }^{184} \mathrm{y}$ ayudó de manera determinante a consolidar y finalizar con éxito el programa de reformas del clero castellano impulsado por el propio Juan $\mathrm{I}^{185}$. Una excelencia que también es aplicable a los restantes capellanes ordinarios de la corte, al menos, a algunos de ellos. Gómez Fernández, por ejemplo, era embajador de Juan I ante el Papa Clemente VII en Aviñón en 1389. Sin duda, su trabajo en la curia pontificia debió de ser satisfactorio tanto para el monarca castella-

${ }^{181}$ D. Nogales Rincón, La representación religiosa de la monarquía Castellano-leonesa: la Capilla Real (1252-1504), Universidad Complutense de Madrid, 3 vols., 2009.

182 J. M. Nieto Soria, Iglesia y génesis del Estado Moderno en Castilla (1369-1480) Madrid, 1993, p. 438. J. De Salazar y Acha, La Casa..., pp. 465 y 466.

${ }^{183}$ Fue cardenal de Sant'Angelo C. Olivera Serrano, Beatriz de Portugal..., pp. 222-229.

184 Sobre el papel desarrollado por estos eclesiásticos en el ejercicio de la diplomacia castellana de la primera mitad del siglo XV véanse los trabajos de F. de P. CAÑAS GÁlVEZ, "La diplomacia castellana durante el reinado de Juan II: la participación de los letrados de la Cancillería Real en las embajadas regias", Anuario de Estudios Medievales, 40/2 (2010), pp. 691-722, y O. Villarroel González, "Eclesiásticos en la diplomacia castellana en el siglo XV", Anuario de Estudios Medievales , 40/2 (2010), pp. 791-819.

185 Véase L. SuÁrez Fernández, Historia del reinado..., I, pp. 351-372. 
no como para el pontífice si tenemos en cuenta que en mayo de ese mismo año fue gratificado con la concesión de una escolastría en Toledo ${ }^{186}$.

El papel de los restantes capellanes documentados en la corte de Juan I fue, al parecer, de un menor brillo institucional. De todos ellos, sobresale por su carrera eclesiástica Juan Martínez de Melgar, que también llegó a ser capellán de Juana Manuel y después de Beatriz de Portugal, además de capellán mayor de la capilla de Reyes Nuevos de la Catedral de Toledo $(1385,1397$, ¿1410? ¿1422?), capellán de la capilla real en Toledo (1403) finalizando su trayectoria en 1403 como beneficiado patrimonial en la iglesia de Santa María de Melgar, año en el que Enrique III también había suplicado en su nombre un beneficio en la iglesia toledana ${ }^{187}$. Por su parte, el capellán Sancho Martínez, monje benedictino, abad de Cabañas y arcediano de Campos, sería el encargado por orden del rey de buscar monjes, junto al confesor Pedro de Belorado, para la constitución de la comunidad monástica de San Benito el Real de Valladolid (1388-1389) ${ }^{188}$.

El papel de los confesores tuvo, si cabe, una mayor relevancia en el entorno regio, pues además de atender las necesidades piadosas más íntimas de los soberanos, el carácter privado de su oficio les permitió no pocas veces actuar como consejeros personales de los monarcas. Ambas vertientes del oficio, la religiosa y la política, quedan integradas magníficamente en la persona del fraile franciscano Fernando de Illescas, confesor de Juan I, Enrique III y Juan II (1382-1407), además de predicador y consejero de Juan I (1389). Junto a su excelencia como eclesiástico, que se vería premiada fuera de las fronteras de Castilla al ser nombrado capellán pontificio de Clemente VII (1382), habría que añadir, al igual que había ocurrido con diversos capellanes reales según ya vimos, sus dotes diplomáticas como embajador ante Carlos II de Navarra (1383), Juan de Gante (1387), Fernando I de Portugal (1389) y Carlos VI de Francia (1396)189. Su protagonismo en la reforma del clero castellano a instancias del rey fue también muy notable. En agosto de 1382 y en septiembre de 1386, por ejemplo, sabemos que era visitador del monasterio de Santa Clara de Tordesillas actuando entonces bajo las órdenes de Clemente VII que había facultado al cenobio para poder aumentar el número de monjas en Santa Clara en vista del aumento de sus rentas ${ }^{190}$.

La labor del resto de confesores reales de este reinado queda un tanto eclipsada por la brillante trayectoria de fray Fernando de Illescas. El más destacado de ellos quizá sea fray Juan Vélez al servicio de Juan I desde, al menos, 1380. Como oficial recibía su correspondiente ración mensual de 40 maravedíes diarios, una de las más altas de la Casa Real, ello, y las mercedes recibidas aquel mismo año, nos inducen

186 V. Beltrán de Heredia, Bulario de la Universidad de Salamanca, (1219-1549), I, Salamanca, 1966, Documento 193, pp. 474-475.

187 D. Nogales Rincón, La representación..., III, p. 2.127.

188 J.M. Nieto Soria, Iglesia y génesis..., p. 446.

189 J.M. Nieto Soria, Iglesia y génesis..., p. 143. J. De Salazar y Acha, La Casa..., p. 473. También A. López Fernández, "Fray Fernando de Illescas, confesor de los Reyes de Castilla Juan I y Enrique III", Archivo Iberoamericano, XXX (1928), pp. 241-252.

190 J. Castro Toledo, Colección diplomática de Tordesillas, Valladolid, 1981, Documentos 220 y 257, pp. 143-144 y 166. 
a pensar que se trataba de una persona especialmente querida por el rey. Además de su elevada ración, habría que añadir una merced de 2.000 maravedíes y otros 1.300 más "para vna pieça de Ypre para se vestir". En abril recibía 1 maravedí de ración y se le entregaban 400 maravedíes en reales de plata para el pago a un "misacantano" (300) y a "una muger por amor DE Dios" (100)191. Disponía en 1380, además, de un "compañero" fray Frutos, con su correspondiente ración de 5 maravedíes diarios, 150 mensuales $^{192}$, y de un criado, Alfonso Fernández, que, a su vez, contaba con una ración de 5 maravedíes diarios, ración que, sin embargo, y por cuanto "este Alfonso Ferrandes non vino a servir", se pagó a Diego Lopes de Rojas, ballestero del rey ${ }^{193}$.

Más difusas son las noticias que tenemos sobre los otros dos confesores reales documentados en este periodo: Alfonso Fernández de Marymón y Pedro de Belorado. Del primero sabemos que en junio de 1380 recibió de López de Estúñiga 7.300 reales de plata, que equivalían a 2.100 maravedíes, "para dar a Dios al conplimiento del rey, nuestro padre, que Dios perdone" 194 , mientras que de Belorado consta que era un fraile mendicante y que entre 1389 y 1390 colaboró activamente con el capellán Sancho Martínez y Juan I en la fundación de San Benito el Real de Valladolid ${ }^{19}$.

A diferencia de capellanes y confesores, los limosneros, como oficiales adscritos a la estructura general de la Capilla Real, se documentan por vez primera en tiempos de Juan I. Su labor, tan asociada a las prácticas de la magnanimidad y espiritualidad regia del bajomedievo, estuvo en un principio desempeñada por capellanes aunque posteriormente el cargo fue ganado ámbitos propios de actuación hasta alcanzar carta de naturaleza propia durante el reinado de los Reyes Católicos ${ }^{196}$. Esta unión funcional de capellanes y limosneros se documenta durante del periodo de nuestro estudio en la persona de Juan Fernández, quien en abril de 1380 aparecía desempeñando ambos oficios. La labor de los limosneros consistía en auxiliar y amparar económicamente a los pobres por orden real. Para este cometido, y los propios de la piedad privada del monarca ${ }^{197}$, los limosneros recibían, al menos desde el reinado de Juan I, el dinero de la cámara real, aunque más tarde estos fondos provinieron de otras rentas reales como los yantares. De este modo, en abril de 1380, el mencionado Juan Fernández cobró del camarero López de Estúñiga 700 maravedíes "para dar de comer a los nuestros pobres"; además de otros 1.955 maravedíes para "que diese de vestir el viernes de endulgençias a los nuestros pobres". Por aquellos mismos días, fray Francisco, limosnero de la reina Leonor de Aragón, recibía de López de Estúñiga 5.000 maravedíes "para que diese limosna a los pobres el viernes de endulgençias".

${ }^{191}$ Librados el 8 de enero y 3 de abril de 1380. AHN, Nobleza, Osuna, Carp. 40, nº 1.

192 Por albalá de 8 de enero de 1380. AHN, Nobleza, Osuna, Carp. 40, $\mathrm{n}^{\circ} 1$.

${ }^{193}$ Por albalá de 4 de febrero de 1380. AHN, Nobleza, Osuna, Carp. 40, $\mathrm{n}^{\circ} 1$.

${ }^{194}$ Por albalá de 15 de junio de 1380. AHN, Nobleza, Osuna, Carp. 40, $n^{\circ} 1$.

195 J.M. Nieto Soria, Iglesia y génesis..., p. 426.

${ }_{196}$ Parece que fue don Pedro de Toledo, primer obispo de Málaga e hijo del relator de Juan II y Enrique IV, en quién recayó por vez primera la dignidad de limosnero. Véase El libro del limosnero de Isabel la Católica. Transcripción y edición por Eloy Benito Ruano, de la Real Academia de la Historia. Madrid 1989, pp. 23-29.

197 Así, en enero de 1380 López de Estúñiga entregó a Juan I 340 maravedíes “para ofreçer el día de Pasqua de Navidad" y otros 240 maravedíes más "para ofreçer el dia de Apariçio Domini”. Por albalá de 8 de enero de 1380. AHN, Nobleza, Osuna, Carp. 40, $n^{\circ} 1$. 
Seguramente los 50 maravedíes que en enero de 1380 el capellán real Gonzalo Martínez recibió del rey para "el nuestro huesped del Viso quando nos por y pasamos" respondían a su doble labor como capellán y también como limosnero, aunque la documentación silencia si efectivamente desempeñaba este segundo oficio ${ }^{198}$.

Junto a capellanes, confesores y limosneros, en la Capilla Real trabajaban otros oficiales encargados de preparar los ornamentos litúrgicos destinados a solemnizar los oficios religiosos. Entre ellos destacaban los organistas, ministriles y cantores, cuya música contribuía de manera determinante a magnificar el boato y la ceremonia en estos actos sagrados. No contamos con datos que nos ilustren sobre el trabajo de estos artistas en la corte de Juan I de Castilla, pero si tenemos en cuenta la brillantez del repertorio para tecla alcanzado en la corte de su cuñado, el infante Juan de Aragón, y la consabida relación musical entre ambos, es posible determinar con cierta seguridad su excelencia debió de ser muy notable. Las noticias que tenemos sobre cantores al servicio de la Capilla Real son también muy escasas y se limitan al ámbito de las reinas consortes. Así, como chantre de Leonor de Aragón aparece Simón de Peris en 1382 o, quizá, antes ${ }^{199}$, y como cantor de Beatriz de Portugal Alfonso Jiménez, quien en 1394 solicitaba ante la curia pontificia una porción íntegra y perpetua en la iglesia de Ávila ${ }^{200}$. Los ministriles, por su parte, debieron de participar en las ocasiones más solemnes, como en la coronación de Juan I en el monasterio de las Huelgas de Burgos. Ya tuvimos ocasión de ver páginas atrás que para aquel acto el infante don Juan de Aragón envió a su cuñado los que por entonces eran sus mejores ministriles, Martí, Oloqui y Midach ${ }^{201}$.

También destacada era la labor de los artesanos a la hora de engalanar la Capilla Real para las celebraciones litúrgicas y realizar los ornamentos necesarios para el desarrollo de los oficios. El trabajo de los alfayates en este sentido era, al igual que ocurría en reinados posteriores ${ }^{202}$, muy notable pues eran los encargados de realizar las vestiduras eclesiásticas y demás telas que se exhibían durante estos actos. Sabemos que el ya mencionado alfayate Bartolomé Martínez fue el responsable de confeccionar "una colcha de sarsahan y... coser y forrar una casulla, una capa y dos almáticas de tapete prieto que nos le mandamos faser para nuestra capilla" ${ }^{203}$.

Por su parte, la elaboración de los ornamentos metálicos requería la participación de los orfebres y plateros. Con el primero de estos oficios aparece desde febrero de 1380 en la corte de Juan I Yehuda Aben Alasar con una ración de 5 maravedíes diarios ${ }^{204}$. A lo largo de los meses de febrero y junio de ese año, este artesano recibió 5.400 maravedíes para comprar un total de 84 marcos de plata y 3 onzas de plata

${ }^{198}$ Todas estas cantidades fueron libradas por albalá de 8 de enero de 1380. AHN, Nobleza, Osuna, Carp. $40, \mathrm{n}^{\mathrm{o}} 1$.

199 En abril de 1384 se encontraba al servicio del padre de Leonor de Aragón, Pedro IV el Ceremonioso. Ma C. Gómez Muntané, La música en la Casa Real..., p. 69.

${ }^{200}$ ASV, Reg. Suppl. 90, fol. 56v.

${ }^{201}$ Véase nota 163.

${ }^{202}$ Para tiempos de Juan II véase F. de P. Cañas Gálvez, “La cámara...”, pp. 140-147.

${ }^{203}$ Por albalá de 3 de abril de 1380. AHN, Nobleza, Osuna, Carp. 40, nº 1.

${ }^{204}$ Por albalá de 10 de julio de 1380. AHN, Nobleza, Osuna, Carp. 40, $n^{\circ} 1$. 
"para faser algunas obras que le nos (el rey) mandamos faser" 205 . Quizá, él mismo, fuera el también el encargado de dorar un "açetre e garsopo e candeleros" que se encontraban en la capilla en noviembre de 1379. También orfebre parece que fue Martín Andrea a quien en julio de 1380 el rey ordenó que se le dieran "tres francos de oro para faser la corona de la reyna que entraron en ella 23 francos de oro" ${ }^{206}$. Sabemos, por último de la labor de maestre Enrique en "las ymajenes para el monimento de rey, nuestro padre, que Dios perdone" en la capilla de los Reyes Nuevos de la Catedral de Toledo, un trabajo por el que en enero de 1380 se le pagaron 4.000 maravedíes ${ }^{207}$.

\section{LA CAZA REGIA: EL PAPEL PROTAGONISTA DE LA CETRERÍA EN TIEMPOS DE JUAN I DE CASTILLA}

La caza practicada por el rey era competencia del mayordomo mayor. La coordinación y supervisión de las monterías recaía en manos del montero mayor que era, además, el encargado de controlar a los furtivos en los cazaderos del monarca y, según apunta Salazar y Acha, de custodiar las armas y arreos propios de la actividad cinegética ${ }^{208}$. Bajo su autoridad participaban en las batidas reales un importante número de oficiales entre los que se encontraban cazadores, diversos tipos de ballesteros, mozos de alanos y, en las ocasiones más señaladas, hasta ministriles y trompetas ${ }^{209}$.

Entre estos oficiales destacaban de manera muy notable la labor de los ballesteros de monte, cuyo principal cometido consistía en seguir los rastros de las piezas que finalmente eran abatidas por el rey. Su valía era apreciada en la corte por sus conocimientos del terreno donde solían trabajar y por ello en ocasiones eran utilizados en otras misiones alejadas de la actividad cinegética. En enero de 1385, por ejemplo, Juan I ordenó a la ciudad de Murcia que dispusiera de seis ballesteros de monte "por quanto en aquellas tierras non ay omnes que sepan seguir los rastros de los almogavares de tierra de moros... salvo los vallesteros de monte..." y evitar así los daños que los granadinos estaban ocasionando en la zona ${ }^{210}$.

También cobraba relevancia en las monterías el trabajo del llamado oficial de la maleta, documentado por vez primera en Castilla en la persona de Álvaro, y a quien en febrero de 1380 se le entregaron 500 maravedíes sin que sepamos el destino de ese dinero ${ }^{211}$. Su principal misión consistía en portar la maleta de color grana en la

${ }^{205}$ Por albalaes de 11 de febrero, 3 de abril y 15 de junio de 1380 . AHN, Nobleza, Osuna, Carp. $40, \mathrm{n}^{\circ} 1$. Es posible que Yehuda fuera el orfebre encargado de realizar algunas de las joyas que Juan I entregó en 1383 a León de Armenia "E otro día el rey don Juan le envió muchos paños de oro e de seda, e muchas joyas...”. P. LóPez de Ayala, Crónica del rey don Juan..., p. 544.

${ }^{206}$ Por albalá de 22 de julio de 1380. AHN, Nobleza, Osuna, Carp. 40, $\mathrm{n}^{\circ} 1$.

${ }^{207}$ Por albalá de 8 de enero de 1380. AHN, Nobleza, Osuna, Carp. 40, nº 1.

208 J. de Salazar y Acha, La Casa..., p. 318. También F. de P. Cañas Gálvez, “La cámara...”, pp. 132-138.

${ }^{209}$ F. de P. CAÑas GÁlvez, "La cámara...", p. 134.

${ }^{210}$ Estos seis ballesteros fueron premiados con la exención de monedas por albalá de Juan I de 24 de enero de 1385. J. M. Díez Martínez, A. Bejarano y A. L. Molina Molina, Documentos ..., Documento 163 , p. 324.

${ }^{211}$ Por albalá de 20 de febrero de 1380. AHN, Nobleza, Osuna, Carp. 40, $\mathrm{n}^{\circ} 1$. 
que se guardaban un “...vestido pardo o verde para el monte o caça, e algunos pañiçuelos de narizes e dos o tres tovallas, e algunos borzeguies e çapatos e pantuflos, e una espada o chavarina o cuchillo de monte e escrivanias e papel e otras cosas" ${ }^{212}$.

Como todos los miembros de la realeza y la alta nobleza, Juan I sintió desde muy joven una gran pasión por la caza. Siendo aún infante $(1371)^{213}$ contó con un montero mayor entre los miembros de su Casa, Fernán Carrillo ${ }^{214}$, quien ostentó este oficio hasta la proclamación del heredero como rey de Castilla, en 1379. Un año más tarde fue nombrado ballestero mayor del rey ${ }^{215}$, cargo que desempeñó, probablemente, hasta su muerte en la batalla de Aljubarrota, en $1385^{216}$. No sabemos con certeza quién fue nombrado montero mayor cuando Juan I llegó al trono. Debieron de ser o bien Rodrigo Rodrigo Álvarez Osorio, antiguo titular del oficio en tiempos de Enrique II (1375) o, quizá, lo fuera su hijo, Lope Álvarez de Osorio, quien con seguridad ya lo desempeñaba en 1385. Un año antes, en 1384, sin embargo, nos figura Pedro González de Valderrábano como montero mayor del rey, probablemente como un lugarteniente del montero mayor. Menos aún son los datos que poseemos de Alvar Rodríguez que en 1389 aparecía únicamente como montero del rey ${ }^{217}$.

Las noticias que tenemos sobre cacerías reales durante este reinado son prácticamente inexistentes aunque algunas fuentes documentales nos permiten entrever la posible participación de Juan I, siendo aún heredero al trono, con su cuñado el infante Juan de Aragón y en las que pudo actuar de mediador u organizador el mayordomo mayor de la esposa del infante castellano Leonor de Aragón, Juan Martínez de Luna. De octubre de 1375, por ejemplo, es una carta del infante aragonés pidiendo disculpas al mayordomo por no poder asistir a "correr mont" por tener que marchar junto a su padre, Pedro IV ${ }^{218}$, y de diciembre de 1377 es otra carta similar en la que el primogénito de Aragón organizaba una batida de caza con Martínez de Luna "en el lugar de Alagon... do trabaremos caça de mont en el rio Exalon" y en la que, quizá, también pudo participar el infante castellano ${ }^{219}$. Unos meses después, en marzo de

${ }^{212}$ Citado por F. de P. Cañas Gálvez, "La cámara...”, p. 119.

${ }^{213}$ Cuando en 1385 cuando Juan I dejó en su testamento nombrados los oficiales de la Casa de sus hijos Enrique y Fernando no mencionó a ningún montero o montero mayor a su servicio. La primera mención a un montero mayor al servicio de don Enrique data de 1389 en la persona de Pedro González de Contreras. De igual modo, tampoco aparece el montero mayor, aunque sí el halconero, en los oficiales de la Casa del príncipe Enrique nombrados por Juan II en abril de 1440. P. LóPEz DE AyALA, Crónica del rey don Juan..., pp. 776-778; D. DE Colmenares, Historia de la insigne ciudad de Segovia, I, Segovia, 1982, p. 523; y P. CARrillo De Huete, Crónica del Halconero de Juan II (Edición de J. de M. Carriazo), Madrid, 1946, pp. 335-336.

${ }^{214}$ Como tal figura en una carta de Enrique II dada en las Cortes de Toro el 20 de septiembre de 1371. AHN, Nobleza, Priego, Carp. 373, nº 20.

${ }^{215}$ Con este oficio figura en una carta real dada en Soria el 17 de septiembre de 1380. J. M. DíEz Martínez, A. Bejarano y A. L. Molina Molina, Documentos..., Documento 42, pp. 78-80.

${ }^{216}$ P. López de Ayala, Crónica del rey don Juan..., p. 603.

217 J. De Salazar y Acha, La Casa..., pp. 317 y 537.

${ }^{218}$ Carta del infante Juan de Aragón dada en Calatayud el 22 de octubre de 1375. ACA, Registro 1.742 , fol. $77 \mathrm{v}$.

${ }^{219}$ En carta del infante fechada en Huesca el 7 de diciembre de 1377. ACA, Registro 1.744, fol. $101 \mathrm{v}$. 
1378, Juan de Aragón devolvía a Martínez de Luna “todos los canes que nos hauedes emprestados" ${ }^{220}$. Para principios de abril de ese mismo año estaba prevista otra montería entre Martínez de Luna, el infante Juan de Aragón y, quién sabe si también el infante castellano, cerca de Calatorao, en la frontera aragonesa con Castilla ${ }^{221}$.

Algo más documentada está la práctica de la cetrería en tiempos de Juan I. Todo lo relacionado con su ejercicio en la corte estaba bajo la autoridad del halconero mayor o cazador mayor. Este noble arte había alcanzado en Castilla durante la segunda mitad del siglo XIV un desarrollo excepcional y los tratados de la época así lo vienen a confirmar. Entre ellos destaca el Libro de la caza de las aves, escrito por Pero LóPEZ DE AYALA durante su cautiverio portugués tras el desastre de Aljubarrota, donde se explica de manera muy exhaustiva la variedad y tipos de halcones preferidos por la realeza y nobleza de Castilla, sobre todo en tiempos de Pedro I222. Las informaciones que nos ofrece López de Ayala quedan contrastadas durante el reinado de Juan I en numerosos documentos del Archivo General de Navarra. Gracias a ellos sabemos que los halcones que poseyó el rey castellano fueron de tal calidad que su fama atravesó las fronteras del reino. Estas aves, como piezas exclusivas, fueron no pocas veces objeto de intercambio entre las diferentes casas reales en el marco de las relaciones diplomáticas. En diciembre de 1383, por ejemplo, Carlos II de Navarra, agradecido, ordenó a los oidores de la Cámara de Comptos y al tesorero que libraran a dos oficiales castellanos un total de 50 florines por haberle prestado en Peralta un par de halcones que le había enviado Juan I de Castilla ${ }^{223}$. Y unos meses más tarde, en marzo de 1384, el monarca navarro volvía a ordenar el pago de 10 libras a otros dos halconeros de Juan I enviados a Navarra ${ }^{224}$. Quizá estos dos halconeros fueran los mismos que en mayo de ese mismo año recibían de Carlos II otra merced de 40 florines ${ }^{225}$.

${ }^{220}$ Así en carta del infante dada en Zaragoza el 4 de marzo de 1378. ACA, Registro 1.744, fol. 128f.

${ }^{221}$ Así en carta del infante despachada en Zaragoza el 31 de marzo de 1378. ACA, Registro 1.744, fol. $135 \mathrm{v}$.

${ }^{222}$ En el libro se citan asimismo los nombres de algunos halconeros de Pedro I de Castilla: Juan Fernández Burrillo, Alfonso Méndez, Ruy González de Illescas (comendador de Santiago), Juan Criado y Fernand García el Romo. También el de un halconero del rey Fernando I de Portugal: Pero Menino; e, incluso el nombre de varios halcones que destacaban en esa época por sus habilidades: Doncella (halcón baharí mallorquín), Botafuego (halcón tagarote), Calahorra (halcón neblí). P. LóPEz DE AyALA, Libro de la caza de las aves, Edición de José Fradejas Lebrero, Madrid, 1986. También F. GómEz REDONDO, Historia de la prosa medieval castellana, II. El desarrollo de los géneros. La f cción caballeresca y el orden religioso, Madrid, 1999, pp. 2036-2049. Una visión de conjunto de este mismo autor sobre los tratados de cetrería en el siglo XIV en pp. 1682-1691.

223 Por orden de Carlos II dada en Tafalla el 22 de diciembre de 1383. AGN, Comptos, Caja 45, $\mathrm{n}^{\circ}$ 95, II. J. R. CAstro, Catálogo..., XIV, Documento 847, p. 351.

224 Por orden de Carlos II fechada en Pamplona el 13 de marzo de 1384. AGN, Comptos, Caja 45, n 27, I. J. R. CAstro, Catálogo..., XV, Documento 145, p. 67.

225 Por orden de Carlos II dada en Pamplona el 3 de mayo de 1384. Ese mismo día se le entregaron también a un "mandadero del rey de Castilla" que estaba enfermo en Pamplona 40 libras. AGN, Comptos, Caja 48, no 47, VI. J. R. CAstro, Catálogo..., XV, Documento 253, p. 116. 


\section{CONCLUSIÓN}

A lo largo de este estudio hemos tratado los aspectos domésticos y de vida cotidiana de la realeza castellana durante el reinado de Juan I. Aquella etapa, caracterizada por la paulatina consolidación de las reformas iniciadas por Enrique II tras ser proclamado rey de Castilla como instrumentos al servicio de la Corona a la hora de consolidar su poder político, cuestionado como es bien sabido por su origen ilegítimo, supuso en el plano de la organización de la Casa Real un salto evolutivo muy notable con respecto a etapas anteriores, de manera que la estructura y organización de la Casa Real era en 1390 muy similar, o, incluso, idéntica, a la de sus sucesores un siglo más tarde.

Una parte sustancial de aquellas reformas en el seno de la Casa del rey vino dada por una renovación absoluta del perfil profesional de los oficiales que desempeñaron aquellos cargos cortesanos. Efectivamente, los Trastámaras, aunque premiaron a sus partidarios con una buena parte de los principales oficios honoríficos áulicos, fueron, sin duda, conscientes de la necesidad de contar en los puestos de gestión y administración con oficiales cualificados para mejorar la acción de gobierno de la monarquía. Ello significó el fortalecimiento del aparato burocrático regio y contribuyó de manera determinante a asentar definitivamente las directrices políticas de la nueva dinastía en Castilla. En el plano más doméstico, y como consecuencia de la creciente actividad administrativa a la que nos estamos refiriendo, también se experimentó un aumento en la cantidad y la calidad de estos oficiales. Por ello, una vez fijadas las bases económicas y políticas de la nueva monarquía, la corte y la persona del rey se convirtieron en escenario y protagonista respectivaemente de aquella representación de un poder regio cada vez más sólido. Todo derivó de manera muy rápida en un incremento de los ajuares regios y en el lujo de las residencias reales como emblemas de una monarquía magnífica y majestuosa que precisaba de una plantilla de oficiales cuyo crecimiento exponencial era preciso para atender con eficacia aquellas necesidades político-institucionales.

Cuando en 1390 fallece Juan I su Casa y Corte eran ya una estructura sólida y bien definida institucionalmente. Los monarcas posteriores fortalecieron aquel modelo hasta alcanzar la perfección durante el reinado de los Reyes Católicos. Sólo la llegada de Carlos I a España en 1517 y las nuevas coyunturas políticas, económicas y burocrático-administrativas de la nueva monarquía determinaron un cambio de modelo en la Casa Real de Castilla. 


\section{APÉNDICE \\ LISTADO DE OFICIALES DE LA CASA DE JUAN I DE CASTILLA}

\author{
MAYORDOMOS \\ MAYORDOMOS MAYORES \\ Pedro González de Mendoza (1367-†1385) \\ Diego Hurtado de Mendoza (1385-1390) \\ Juan Hurtado de Mendoza (1390-†1419) \\ MAYORDOMO \\ Fernando Díaz de Mendoza (1379) \\ OTROS OFICIALES DEPENDIENTES \\ DEL MAYORDOMO MAYOR
}

DESPENSEROS MAYORES

Ferrant Gascón (1374-1386)

Juan Gómez (1379)

Juan Núñez (1379-1388)

DesPenseros

Santiago García (1385)

Pedro Martínez (1379)

Despensero de los CABalleros del Rey y Del INFANTE DON ENRIQUE

Juan de San Pedro (1385)

CABALlerizo

Sancho García (1379)

ACEMILERos MAYORES

Juan García de Villoldo (1379)

Pedro González Carrillo (1386)

Pedro Rodríguez de Fonseca (1386)

Acemileros

García Sánchez (1378)

Juan Ruiz (1379)

Gonzalo Ruiz (1380)

Servidor de la CUAdRa

Pedro Ferrándiz (1383)
COPEROS MAYORES

Alvar García de Albornoz (1380-1385)

Juan de Albornoz (1385-1389)

Veedor de la Casa del Rey

Pero Sánchez del Castillo. Oidor de la Audiencia Real (1388)

LA CÁMARA REGIA

CAmareros mayores

Juan Carrillo (1375-†1386)

Pedro Fernández de Velasco (1379-†1384)

Juan de Velasco (1384-†1418)

Camareros

Diego López de Estúñiga (1377-1388)

Alfonso Ruiz (1379)

Ruy Fernández (1379-1380)

Juan Sánchez (1380)

Gonzalo Rodríguez (1380)

Camarero mayor de la cámara de los paños DEL INFANTE DON ENRIQUE

Diego López de Estúñiga (1385)

Camarero de la Cámara de la Jineta del INFANTE DON ENRIQUE

Domingo Fernández (1380)

REPOSTEROS MAYORES

García Fernández Sarmiento (1385)

Diego Gómez Manrique (1378-1379-†1385)

Diego Gómez Sarmiento (1380-†1386). Repostero mayor del rey (1380)

Oficial de La escudilla del INFANTE don ENRIQUE

Juan Duque (1385)

TRINCHANTE DEL INFANTE DON ENRIQUE Juan Martínez de Medrano (†1385) 
Aposentadores mayores

Pedro González Carrillo $(\uparrow 1385)$

Pedro Rodríguez de Fonseca (1386-1402)

Aposentador

Pero Sánchez (1390)

DONCEL

Juan Álvarez (1380)

Físicos

Mayer Algoadix (1383-1384)

Juan Guillén (1385)

¿Jacob (1387)?

Mosé Aben-Abraham Aben Zarzal (¿?)

Maestre Berenguel (¿?)

PARTERA

Nabona Nada (1379)

JUGLARES

Juan de Alemania (1380)

Angeli (1380)

Pedro (1380)

MinistriLES

Johan Bocs (1373)

Johan Bruniqui (1373)

Johan de Gales (1373)

Johan de Sanç (1373)

Juan de Alemania (1380)

Ministril de ARPA DE JuAn I y DEL INFAnTe ENRIQUE

Johani Auber (1380-1381)

MinistriLES DE BOCA

Mongicot (1387)

"Filz de bon padre" (1387)

MinisTRIL DE CHIRIMÍA

Colinet (1388)

MinistRIL DE CUERDA

Jaquet Portaubert (1385)
Músico

Cristófol de Eslavonia (1380)

TROMPETA

Juan de Alemania (1380)

Alfayates

Bartolomé Martínez (1379-1380)

Gabrer (1380)

Pellejero

Salamón (1379)

BORDADORES

Maestre Lope (1379-1380). Sellero del rey en 1379

Ferrant González (1380)

ORFEBRE

Yehuda Aben Alasar (1380)

BARRENDERA

Juana Martínez (1379)

FRUTERO

Juan Sánchez de Medina (1380)

Monteros MAYORES

Lope Álvarez Osorio (1385)

Fernán Carrillo (1373-1379)

Pedro González de Valderrábano (1384)

MONTERO

Alvar Rodríguez (1389)

SELLERO

Maestre Lope (1379). Entre 1379 y 1389 fue bordador del rey

Solador del palacio Real de Soria

Maestro Çuleman (1380)

CRIADOS

Bartolomé Rodríguez de Sevilla (1380)

Bartolomé Martínez de Sevilla (1380) 


\section{LA CAPILLA REAL}

\section{CApellanes mayores}

Rodrigo de Moscoso, arzobispo de Santiago $(1367-1380-\uparrow 1382)$

Juan García Manrique, arzobispo de Santiago (1382-1389)

Capellanes

Gómez Fernández (1389)

Juan Fernández (1380). Limosnero del rey en 1380

Gonzalo Martínez (1380)

Sancho Martínez (1388-1389)

Juan Martínez de Melgar (¿?)

CONFESORES

Pedro de Belorado (1389-1390)

Alfonso Fernández Marymón (1380)

Fray Juan Vélez (1380)

CONFESOR MAYOR

Fray Fernando de Illescas (1382-1406)

COMPAÑERO DEL CONFESOR REAL

Fray Frutos (1380)

CRIADO DEL CONFESOR

Alfonso Fernández. En su lugar el ballestero

Diego López de Rojas (1380)

Predicador

Fray Fernando de Illescas (i?)

LIMOSNERO

Juan Fernández (1380). Capellán del rey.

\section{LOS OFICIOS BUROCRÁTICOS}

CANCILLERES MAYORES

Sancho, obispo de Oviedo (1370)
Martín, obispo de Plasencia (1375)

Juan García Manrique, arzobispo de Santiago (1379-1391). Canciller mayor de la reina Juana Manuel en 1380

CANCILleres

Alvar Martínez de Villarreal (1380-1386). En 1379 aparece como tesorero y entre 1380 y 1390 como doctor y oidor de la Audiencia Real.

Alfonso Sánchez (1383)226

CAncilleres del Sello de la PORIDAD

Juan Martínez (1389-1409). Escribano del rey entre 1380 y 1389 , escribano de cámara entre 1385 y 1389 y escribano del Consejo Real en 1386.

Juan Serrano, obispo de Segovia (13851390)

\section{Consejeros}

Pedro Tenorio, arzobispo de Toledo (13851399)

Juan García Manrique, arzobispo de Santiago (1387)

Pedro Álvarez de Albornoz, arzobispo de Sevilla (1387-1388)

Gonzalo de Mena, obispo de Burgos (1387)

Alfonso de Aragón, marqués de Villena (1387)

Gutierre de Toledo, obispo de Oviedo (1385)

Lope Alfonso (1386)

Fernán Alfonso de Aldama (¿?)

Pero Boyl (1388-1389). Mayordomo del duque de Gerona, don Juan de Aragón (1377). Oficial sin indicación de oficio o cargo en Castilla (1380-1388)

Sancho Boyl (1388)

Gundisalvo García. Doctor en leyes (1389)

Pero García (1385)

Tello García. Doctor en decretos (1389)

${ }^{226}$ Como tal refrenda el Tratado de El Espinar entre el infante don Carlos de Navarra y Juan I. El Espinar, 19 de octubre de 1383. AGN, Comptos, Caja 39, nº 21. 
Pero García de Peñaranda (1387). Alcalde y guarda de las sacas y cosas vedadas del obispado del obispado de Cartagena y reino de Murcia (1390)

Ruy González de Salamanca (1386-1387)

Pero Fernández de Burgos (¿?)

Alfonso Fernández de Montemayor (13851387)

Fray Fernando de Illescas (1389)

Gundisalvus Gundisalvi (i?)

Juan Hurtado de Mendoza (1387-1388)

Pero López, arcediano de Alcaraz (i?)

Juan Martínez de Rojas (1383). Alcalde mayor de los fijosdalgo (1379). Oidor de la Audiencia Real (1380).

Ruy Pérez (1385)

Ruy Pérez Esquivel (1385-1387). Contador de Enrique II (1374-1378).

Juan de San Juan (1386-1387)

Antonios Sancius ( $₫$ ?)

Juan Serrano (Presidente, 1390)

Pero Suárez de Quiñones (1387)

Juan de Villacreces (1389). Embajador de Juan I. Obispo de Calahorra (1382-1394). Obispo de Burgos (1394-1406)

\section{CONTAdORES MAYORES}

Ruy Bernal (1386)

Alfonso Bernal de Sevilla (1390-1393). ¿Caballero en la collación de Santa Catalina de Sevilla en 1384 ?

Francisco Fernández (1383)

Pero Fernández (1383)

Pero Fernández de Villegas (1385)

Alfonso García de Cuéllar (1390)

Alfonso Sánchez del Castillo (1380-1382)

Juan Sánchez de Sevilla (1388). Samuel Abravanel antes de su bautismo. Tesorero mayor de Beatriz de Portugal (13861388) y tesorero mayor de Andalucía (1388-1391)

Justicias Mayores de la CASA del Rey

Juan Núñez de Villazán (1371-1384)

Diego Gómez Sarmiento $(† 1385)$
Diego Hurtado de Mendoza (1389)

\section{SeCretarios}

Diego Pérez. Secretario de Enrique II (1375)

Pero Sánchez de Torres. Secretario de Enrique II (1375). Canónigo de León. Notario por autoridad del Papa. Notario público

Marcos Alfonso (1386). Lugarteniente del notario mayor de Castilla (1381). Escribano de la notaría mayor de Castilla (1386)

Juan Fernández (1386)

ESCRIBANOS

Juan Alfonso (1380)

Gonzalo Alfonso de Logroño (1389)

Gonzalo Alfonso de Pina (1388-1390)

Ferrand Arias (1380-1385)

Ferrand Berltand (1387)

Alfonso Fernández (1379-1385)

Diego Fernández (1379-1382)

Gonzalo Fernández (1379-1385)

Juan Fernández (1380-1390)

Luis Fernández (1379-1381)

Martín Fernández (1383)

Pero Fernánez (1379-1386)

Ruy Fernández (1379-1384)

Domingo Fernández del Castillo (1382)

Alfonso Fernández de León (1380-1385)

Pero Fernández de Sober (1390)

Alfonso García (1382)

Diego García (1389)

Nicolás García (1380-1383). Escribano de la notaría mayor de Castilla (1382)

Juan García (1384-1388)

Pero García (1385-1387)

Alfonso Gómez (1383-1384)

Ferrand Gómez (1383-1388)

Juan Gómez (1384)

Nicolás Gómez (1383)

Bernal González (1384-1387). Contador y escribano de Sevilla (1384). Escribano mayor de Sevilla (1390) 
Diego González (1390). Escribano de la Audiencia Real (1381-1385). Escribano de cámara del rey (1388)

Ferrand González (1383)

Pero González (1388)

Juan Gutiérrez (1388)

Ruy Gutiérrez (1385). Escribano del Consejo Real (1385)

Ferrand López (1387)

Gonzalo López (1379)

Martín López (1379-1387)

Pero López de Santiesteban (1388)

Alfonso Marques (1380)

Diego Marques (1380-1384)

Alfonso Martínez (1385)

Ferrand Martínez (1381)

Juan Martínez (1380-1389). Canciller del sello de la poridad (1389-1409). Escribano de cámara (1385-1390). Escribano del Consejo Real (1386)

Diego Pérez de Salamanca (1375). Escribano de Enrique II (1375). Encargado de pregonar las paces firmadas con Aragón (1375)

Bartolomé Rodríguez (1389-1390). Escribano del Consejo Real (1388-1389). Escribano de cámara del rey (1390-1406)

Diego Rodríguez (1380)

Pero Rodríguez (1379)

Pero Rodríguez de Écija (1389)

Alfonso Ruiz (1379-1382). ¿Escribano de la Audiencia Real? (1381). Escribano de cámara del Consejo Real (1387-1402). Escribano de cámara del rey (1387-1402)

Fernant Ruiz (1386)

Alfonso Sánchez (1379.1380)

Juan Sánchez (1379-1383)

Manuel Sánchez (1380)

Pero Sánchez de Ávila (1388). Escribano de la notaría mayor de Castilla (1386). Escribano de la notaría mayor de Andalucía (1388-1407). Notario de Andalucía (1401-1412)

Juan Sánchez (1379)

Juan Sánchez de Cuéllar (1389-1390)
Juan Sánchez de Cuenca (1380)

Pero Yáñez (1380)

ESCRIBANO DE LOS ALCALDES

Ferrand Arias (1379)

Escribano del alcalde de CAstilla

Nuño Alfonso (1380)

ESCRIBANO DE LA ALCALDÍA DE LOS FIJOSDALGO Juan Fernández (1380)

Escribanos de la Audiencia Real

Pero Alfonso (1380). ¿Escribano de cámara del rey? (1390)

Pedro Bernal (1382)

Diego Fernández (1379-1381)

Juan Fernández (1379-1388)

Luis Fernández (1380)

Pero Luis Fernández (1382)

Ruy Fernández (1379-1387)

Alfonso Fernández de León (1385-1411)

Gonzalo Fernández de León (1382)

Gonzalo Ferranz (1381)

Diego González (1381-1385). Escribano de cámara del rey (1388). Escribano del rey (1390)

Nicolás Gutiérrez (1380)

Gonzalo López (1379)

Pero López (1381)

Aparicio Rodríguez (1379-1388)

Alfonso Ruiz (1381). ¿Escribano del rey? (1379-1382). Escribano de cámara del consejo Real (1387-1402). Escribano de cámara del rey (1385-1389)

Juan Sánchez (1381)

Juan Sánchez (1390)

Juan Sánchez de Madrigal (1380-1386). Escribano del Consejo Real (1386)

ESCRIBANOS DE CÁMARA

Pero Alfonso (1390). ¿Escribano del Rey? (1380)

Gutierre Díaz (1389-1413) 
Nicolás Fernández (1386-1389). Notario público. Escribano del Consejo Real (13881402)

Diego García (1385-1390)

Juan García (1387-1390). Escribano del Consejo Real (1385)

Alfonso González (1387)

Diego González (1388). Escribano de la Audiencia Real (1381-1385). Escribano del rey (1390)

Juan López (1387)

Ruy López (1386-1395). Escribano del Consejo Real (1387). Regidor de Sevilla y pagador de los castillos y villas fronteras de Granada (1395)

Juan Martínez (1385-1390). Canciller del sello de la poridad (1389 y 1409). Escribano del rey (1380-1389). Escribano del Consejo Real (1386)

Bartolomé Rodríguez (1390-1406). Escribano del Consejo Real (1388-1389). Escribano del rey (1390). Recaudador mayor de los obispados de Salamanca y Ciudad Rodrigo (1406)

Alfonso Ruiz (1385-1389). ¿Escribano del rey? (1379-1382). Escribano de la Audiencia Real (1381). Escribano del Consejo Real (1387-1402)

Juan Sánchez (1383-1386)

Escribanos del Consejo Real

Juan Fernández (1388)

Nicolás Fernández (1388-1402). Escribano de cámara del rey (1389)

Juan García (1385). Escribano de cámara del rey $(1387-1390)$

Ruy Gutiérrez (1385). Escribano del rey (1385)

Ruy López (1387). Escribano de cámara del rey (1386)

Juan Martínez (1386). Canciller del sello de la poridad (1389-1409). Escribano del rey (1380-1389). Escribano de cámara (1385-1390)
Bartolomé Rodríguez (1388-1389). Escribano del rey (1389-1390). Escribano de cámara real (1390-1406)

Alfonso Ruiz (1387-1402). Escribano del rey (1379-1382). Escribano de la Audiencia Real (1381). Escribano de cámara real (1385-1389)

Juan Sánchez de Madrigal (1386). Escribano de la Audiencia Real (1380-1386)

EsCRIBANO PÚBlico DEL CONCEJO DE LAS MESTAS DE LOS PASTORES Y CAÑADAS

Bernardo Martínez (1383-1389). Notario público

LUGARTENIENTE DEL ESCRIBANO PÚBLICO DEL concejo de las Mestas de los pastores Y CAÑADAS

Alfonso Álvarez de Santa Cruz (1384)

ESCRIBANO DE LOS CONTADORES

García Pérez (1383)

ESCRIBANO DE LA TABLA DEL REY

Martín Sánchez (1385)

EsCribanos DE LA NOTARÍA MAYOR DE ANDALUCÍA

Alfonso Fernández de León (1385-1411)

Pero Sánchez de Ávila (1388-1407). Escribano de la notaría mayor de Castilla (1386). Escribano del rey (1388). Notario de Andalucía (1401-1412)

ESCRIBANOS DE LA NOTARÍA MAYOR DE CASTILlA Marcos Alfonso (1386). Lugarteniente de la notaría mayor de Castilla (1381). Secretario del rey (1386)

Bartolomé Arnáiz (1381)

Nicolás García (1382). Escribano del rey (1380-1383)

Pero Sánchez de Ávila (1386). Escribano de la notaría mayor de Castilla (1386). Escribano del rey (1388). Escribano de la 
notaría mayor de Andalucía (1388-1407). Notario de Andalucía (1401-1412)

Notarios mayores de Andalucía

Per Afán de Ribera (1386-1411)

Ferrand Arias (1380)

Juan Fernández Gallego. Lugarteniente (1387)

Pero González de Aranda. Lugarteniente (1382)

Juan González de Avellaneda (1386)

Diego Marques. Lugarteniente (1384)

Pero Suárez de Guzmán (1379-1382)

Gonzalo Vázquez (1385)

Notarios mayores de Castilla

Marcos Alfonso. Lugarteniente de la notaría mayor de Castilla (1381). Escribano de la notaría mayor de Castilla (1386). Secretario del rey (1386)

Arellano (1385)

Diego López Pacheco (1379-1382)

Ferrand Sánchez (1379)

Notarios mayores del Reino de León

Juan García Manrique, arzobispo de Santiago (1382-1389)

Rodrigo de Moscoso, arzobispo de Santiago $(1370-\uparrow 1382)$

Notarios de Castilla

Juan Fernández (1386)

Pedro Suárez (1390). Adelantado de León

Notario del Reino de LeÓN

Martín Ibáñez (1384)

Notarios mayores del Reino de Toledo

Pero Suárez de Toledo (1379-1385). Notario mayor de Andalucía (antes de 1377)

Diego López Pacheco (1380-1382)

Alfonso Tenorio (1384-1425)
Notario MAYOR DE LOS PRIVILEGIOS RODADOS Juan García Manrique (Notario mayor de los privilegios rodados desde 1367). Arzobispo de Santiago de Compostela (13831388)

Pedro de Soria (1379-1401)

Oidores de la Audiencia Real

Juan Alfonso (1374-1385). Doctor en leyes $\mathrm{y}$ en decretos

Pedro Álvarez de Albornoz (1390). Arzobispo de Sevilla (1379-1390)

Ruy Bernal (1379-1390). Doctor (1390)

Arnal Bonal (1385-1390). Doctor en decretos

Alfonso de Córdoba (1390). Obispo de Zamora (1386-1395)

Girón Corón de Oviedo (1385)

Diego de Corral (1374-1390)

Pero Fernández (1379-1384). Doctor en leyes

Pero Fernández de Burgos (1380). Doctor

Pedro Fernández de Frías (1390). Obispo de Osma (1379-1410)

Pero Ferranz (1381-1382. Doctor en leyes (1382)

Ruy Fernández (1380). Doctor

Juan García Manrique (1376-1382). Arzobispo de Santiago de Compostela (13831388)

Gonzalo González de Bustamante (1390). Obispo de Segovia (1389-1392)

Pero López (1388)

Pero López de Ayala (1380-1390). Doctor (1390)

Diego Martínez (1390). Doctor (1390)

Alvar Martínez Ramírez (1381-1382)

Juan Martínez de Rojas (1380). Alcalde mayor de los fijosdalgo (1379). Consejero real (1383)

Alvar Martínez de Villarreal (1380-1390). Doctor (1380). Tesorero del rey (1389). Canciller del rey (1380-1386)

Gonzalo de Mena (1390). Obispo de Burgos (1382-1394) 
Gonzalo Moro (1390). Alcalde de la corte (1385). Doctor (1385)

Alvar Núñez (1384). Doctor

Alfonso Rodríguez (1388-1390). Doctor

Antón Sánchez (1390). Doctor (1390)

Sancho Sánchez (1379)

Pero Sánchez del Castillo (1385-1390). Doctor (1385-1390). Veedor de la Casa del rey $(1388)$

Pedro Tenorio (1380-1390). Arzobispo de Toledo (1377-1399)

Garci Gutierre de Toledo. Doctor. Obispo de Oviedo (1379-1386)

\section{TESOREROS}

Alvar Martínez de Villarreal (1379). Canciller del rey (1380-1386). Doctor y oidor de la Audiencia Real (1380-1390)

Alfonso Díaz de Illescas $(1382)^{227}$

TESORERO MAYOR

Juan García de Areilza (1374-1375)

Tesorero mayor de Castilla

Diego Gil de Tordesillas (1388). Tesorero mayor del obispado de Burgos (1389)

TESORERO MAYOR DE TOLEDO

Gómez García (1379-1380)

Tesorero mayor de las Merindades de Castilla con los obispados de Ávila y SeGOVIA

Diego Fernández de Villegas (1379-1380)

Tesorero mayor del Reino de Galicia

Juan Núñez (1379-1380)

Tesoreros mayores del Rey en Andalucía Miguel Ruiz (1377-1385)

${ }^{227}$ Fue el encargado de entregarle al infante don Carlos de Navarra los 100.000 maravedíes que Juan I de Castilla le había otorgado para el mantenimiento de su estado en tierras castellanas. AGN, Comptos, Registro 172, fol. Fol. 34r.
Juan Sánchez de Sevilla (1388-1391). Samuel Abravanel antes de su bautismo. Contador mayor del rey (1388). Tesorero mayor de Beatriz de Portugal (13861388)

TEsorero MAyor EN EL ARZOBispado DE Toledo Diego Gómez de Almaraz (1388)

Tesorero mayor del obispado de Burgos

Diego Gil de Tordesillas (1389). Tesorero mayor de Castilla (1388)

Alcaldes

Gil Blázquez (1380)

Diego Fernández (1386)

Pedro Fernández (1375)

Alvar Méndez (1379). Doctor en leyes

Gonzalo Moro (1385). Doctor (1385). Oidor de la Audiencia Real (1390)

García Pérez de Camargo (1386)

Juan Rodríguez de Toledo (1379-1382)

Alcaldes de Castilla

Juan Sánchez (1390). Doctor

García Pérez de Camargo (1390)

Alcaldes de LeÓN

Nicolás Gutiérrez (1390)

Ferrand Sánchez (1390)

Alcaldes de las Extremaduras

Gómez Fernández de Cuéllar (1390)

Juan Alfonso del Durazno (1390). Doctor

Alcalde de Toledo

Juan Rodríguez (1390)

Alcalde de Andalucía

Juan Rodríguez (1390). Doctor

Alcalde MAYOR DE las CAÑAdAs. EnTREGAdor MAYOR DEL CONCEJO DE LA MESTA

Juan Martínez de Soto (1379-1384)

Alvar Rodríguez Cueto (1388) 
LUGARTENIENTE DEL ALCALDE DE LAS CAÑADAS Y ENTREGADOR DEL CONCEJO DE LA MESTA DE LOS PASTORES

Gonzalo Mateos (1383-1384)

Alcalde de las cañadas de ÚBeda Alfonso de Ribera (1384)

Alcaldes en el adelantamiento mayor de MurCiA

Diego Pérez de Hinestrosa (1382)

Juan Sánchez Manuel (1370-1382)

Alcalde de las alzadas

Gómez Fernández de Toro (1390)

Alcaldes de los fiJosdalgo

Diego Fernández (1380)

Juan de San Juan (1390)

Diego Sánchez (1390)

AlCalde mayor De los FiJosdalgo

Juan Martínez de Rojas (1379). Oidor de la Audiencia (1380). Consejero real (1383)

Alcaldes y guardas de las sacas y cosas vedadas del obispado de CaRTagena y REINO DE MURCIA

Pedro García de Peñaranda (1390). Vecino de Segovia. Consejero real (1387)

Pedro Tenorio. Arzobispo de Toledo (1390)

Alguacil mayor de Castilla

Alvar Pérez de Guzmán (1379)

Alguacil de la CORTE

García Lorencio (1389)

Merinos mayores en tierra de GuipúzcoA

Pero López de Ayala (1383)

Pero Manrique (1367-¿?)

Pregonero

Pedro García (1375)
Prestamero mayor de Vizcaya

Juan Hurtado de Mendoza (1375)

Otros oficiales de la CANCillería y la AuDIENCIA REAL

Gonzalo Alfonso (1382)

Lope Alfonso (1387)

Juan Alfonso (1382-1390)

Rodrigo Alfonso (1381)

Ferrand Álvarez (1388-1390)

Alvarus (1379-1386). Doctor en decretos

Martín Anes (1387)

Ferrand Arias (1383-1385)

Alfonso Bernal de Sevilla (1390)

Martín Eanes (1379)

Alfonso Fernández (1384-1388)

Bernal Fernández (1383)

Diego Fernández (1382-1385)

Domingo Fernández (1374)

Francisco Fernández (1372)

Francisco Fernández (1383-1387)

Pero Fernández (1388)

García Fernández (1381-1390)

Gómez Fernández (1383-1390)

Gonzalo Fernández (1379-1389)

Juan Fernández (1379-1389)

Martín Fernández (1380)

Pero Fernández (1380-1388)

Petrus Fernández (1379-1383). Doctor

Rodrígo Fernández (1390)

Rui Fernández (1389)

Gómez Ferranz (1390)

Gonzalo Ferranz (1389)

Alfonso García (1389-1390)

Juan García (1385-1390)

Pero García (1387)

Ferrand Garci (1382)

Alfonso González (1387-1389)

Aparicio González (1379)

Garci González (1387-1388)

Juan González (1382)

Gundisalvus Gundisalvi (1389). Doctor en leyes.

Iuanes (1379)

Pero López (1379) 
Diego Marques (1382-1385)

Alfonso Martínez (1379)

Pero Martínez (1389-1390)

Ochoa Meléndez (1388)

Alfonso Rodríguez (1387-1388)

Juan Rodríguez (1379)

Pero Rodríguez (1379)

Alfonso Sánchez (1380-1382)

Antonio Sánchez (1388-1389). Doctor en decretos

Juan Sánchez (1387-1388)

Juan Sancho (1389)

Yáñez (1379)

LOS OFICIOS MILITARES Y DE LA SEGURIDAD DE LA CASA DEL REY

AdALIDES

Juan Martínez (1385)

Juan Gómez de Peralta (1385-1386)

Adelantados mayores de Castilla

Diego Gómez Manrique (1380-1385)

Pero Manrique (1379-1380)

Diego Gómez Sarmiento (1379-1380-†1385)

Adelantados mayores de LA Frontera

Alfonso Fernández de Montemayor (13701380)

Pedro Muñiz de Godoy. Maestre de Calatrava (1382-1383)

Juan Alfonso de Guzmán. I conde de Niebla (1388-1394)

Adelantados mayores del Reino de Galicia

Pero Ruiz Sarmiento (1379- $\uparrow 1384)$

Pero Suárez (1382)

Diego Gómez Sarmiento $(† 1385)$

Adelantado mayor del Reino de León y AsTURIAS

Pero Suárez de Quiñones (1370-1390)

Adelantados mayores de Murcia

Juan Sanchez Manuel (1371-1383)
Alfonso Yáñez Fajardo (1383-1390). Lugarteniente por Juan Sánchez Manuel (13791383)

Alfonso Yáñez Fajardo (1383-1388)

Martín Alfonso de Valdivielso (1382-1383)

AlFÉRECES MAYORES

Juan Hurtado de Mendoza (1372-1386)

Infante Enrique de Castilla (1385)

Juan González de Avellaneda (1385-1393)

Alférez mayor del Pendón de la Banda

Pero López de Ayala (1371-1385)

Alférez mayor del Pendón de la Divisa del REY

Carlos Ramírez de Arellano (1387-1412)

Alférez de los ballesteros

Alfonso Fernández de Villalpando (1379)

AlfÉREZ

Rodrigo Alfonso de Sevilla (1385)

Almirantes mayores de la mar

Fernan Sánchez de Tovar (1379-†1384)

Juan Fernández de Tovar (1384-†1385)

Juan Hurtado de Mendoza (1387)

Armeros

Alfonso Ruiz (1380)

Alonso Martínez (1385)

BALLESTERO MAYOR

Fernán Carrillo (1380-1382-†1385)

BALlesteros

Rodrigo Alfonso de Sevilla (1385-1386)

Ferrant Álvarez de Sevilla (1380)

Pero Fernández (1379)

Ruy Fernández de Becerril (1380)

Alfonso Fernández de Castroverde (1380)

Alfonso Fernández de Palencia (1380)

Pascual García (1380)

García González (1380) 
Lope González (1380)

Juan González de Tordajos (1379)

Ruy López (1379)

Diego López de Rojas (1380)

Juan Sánchez (1380)

Ruy Torres (1380)

BALLESTEROS DE MAZA

Alfonso Fernández de Toledo (1380)

Juan González (1380)

Juan López (1382)

Lope Sánchez (1389)

Caudillo mayor de los escuderos del Rey Juan González de Avellaneda (1380)

Condestable ${ }^{228}$

Alfonso de Aragón (1382-1391)

Cómitres ReALes

Juan Lorenzo (1385)

Esteban Martín (1385)

Alfonso Fernández de España (1386)

Pedro Fernández de Jerez (1388)

Alfonso García (1388)

ESCUDERO

Alfonso de Cuéllar (1379)

GUARDAS

Alvar González de Herrera (1380)

Pero Jiménez Charrín (1379)

Pero Ordóñez de Encinas (1380)

GUARDAS MAYORES

Sancho Fernández de Tovar (1375-1394)

Íñigo Ortiz de Zúñiga (1380)

Men Rodríguez de Biedma (1361-1380)

Pedro Rodríguez de Fonseca (1386)

${ }^{228}$ El oficio fue creado por Juan I a favor de Alfonso de Aragón, marqués de Villena, por carta real dada en el Real sobre Ciudad Rodrigo el 6 de julio de 1382. BN, Ms. 6.932, fols. 314-319. Publicado por L. SuÁrez Fernández, Historia del reinado..., II, Documento 307, pp. 444-446.

\author{
Mariscales del Rey o de LA hueste 229 \\ Ferrand Álvarez de Toledo (1382-1384) \\ Diego Fernández (1387) \\ Diego Gómez Sarmiento (1382-†1385) \\ Pero González Carrillo (†1385) \\ García González de Herrera (1387) \\ Pero Ruiz Sarmiento (†1384) \\ Porteros de la Casa del Rey \\ Pero García (1375-1406) \\ Alfonso García (1385)
}

\section{OTROS OFICIALES SIN INDICACIÓN DE OFICIO O CARGO EN LA CASA DEL REY}

Adam (1379-1380)

Pero Alfonso Girón (1380)

Pero Alfonso de Valladolid (1380)

Luis Boyl (1380)

Ramón Boyl (1380)

María de Cisneros (1380)

Alfonso Fernández de Valladolid (1380)

Fray Pedro García (1380)

Diego González (1379)

Martinus González (1381)

Fray Diego López (1380)

Moricote (1380)

Fray Nicolás (1380)

Alvar Pérez (1379)

García Pérez Becerro (1379)

Juan Ramírez Carro de Rueda (1380)

Fray Pedro Romero (1380)

Antón Sánchez (1379)

Antón Sánchez de Villarreal (1380). Tesorero mayor de Andalucía (1393)

Fray Fernando de Urueña (1380)

${ }^{229}$ Año 1382 “... e estos oficios (junto al de condestable) nunca fueron en Castilla fasta aquí.". P. López de Ayala, Crónica del rey don Juan ..., p. 536. 